\author{
Supporting Information
}

\title{
High Performance Optical Power Limiting Filters at Telecommunication Wavelengths: When Aza-BODIPY Dyes Bond to Sol-gel Materials
}

Sylvain David,a,e Denis Chateau, ${ }^{\mathrm{a}, \mathrm{e}}$ Hao-Jung Chang, ${ }^{\mathrm{b}}$ Cesar Lopes, ${ }^{\mathrm{c}}$ Linda Helena Karlsson, ${ }^{\mathrm{c}}$ Mykhailo V. Bondar, ${ }^{\mathrm{d}}$ Boris Le Guennic, ${ }^{\mathrm{e}}$ Denis Jacquemin, ${ }^{\mathrm{f}}$ Gérard Berginc, ${ }^{\mathrm{g}}$ Olivier Maury, ${ }^{\mathrm{a}, *}$ Stéphane Parola, ${ }^{\mathrm{a}, *}$ Chantal Andraud a,*

a. Dr. S. David, Dr. D. Chateau, Dr. O. Maury, Prof. S. Parola, Dr. C. Andraud ; Univ. Lyon, ENS Lyon, CNRS, Université Lyon 1, Laboratoire de Chimie, UMR 5182, 46 Allée d'Italie, 69364 Lyon, France

E-mail: chantal.andraud@ens-lyon.fr, olivier.maury@ens-lyon.fr, stephane.parola@ens-lyon.fr;

b. H.-J. Chang, CREOL, The College of Optics and Photonics, University of Central Florida, Orlando, FL 32816, USA

c. Dr. L. H. Karlsson, Dr. C. Lopes; Electrooptical Systems Swedish Defence Research Agency (FOI) Linköping SE-581 11, Sweden.

d. Dr. M. V. Bondar; Institute of Physics NASU, Prospect Nauki, 46, Kyiv-28, 03028, Ukraine

e. Dr. B. Le Guennic ; Univ. Rennes, CNRS, ISCR (Institut des Sciences Chimiques de Rennes) UMR 6226, 35000 Rennes, France

f. Prof. D. Jacquemin ; CEISAM UMR 6230, CNRS, Université de Nantes, F-44000 Nantes, France.

g. Dr. G. Berginc ; Thales LAS France, 2 Avenue Gay Lussac, 78990 Élancourt, France

${ }^{£}$ Both authors contributed equally to the project. 
1) Synthetic schemes.

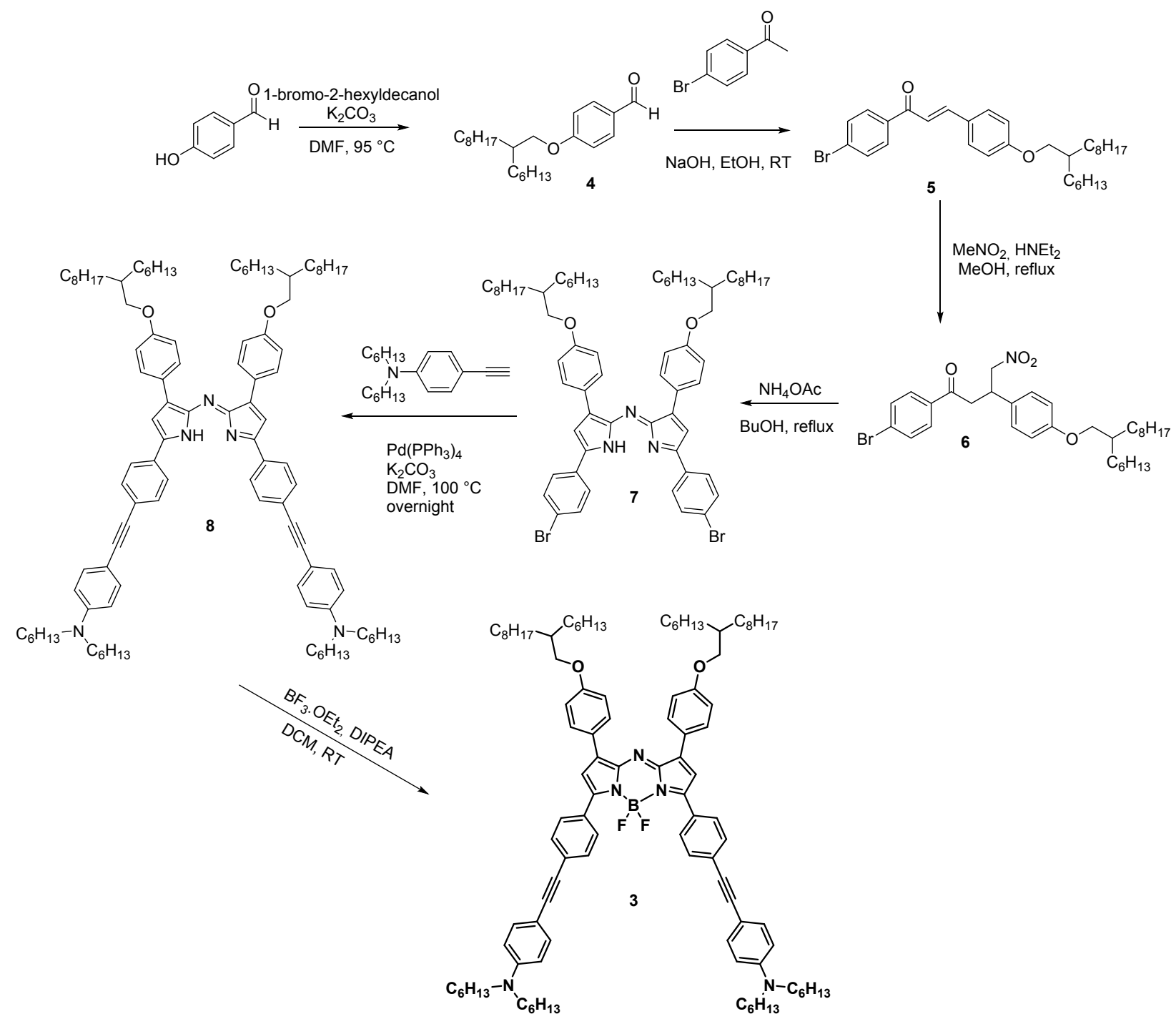

Scheme S1. Synthesis of compound 3. 


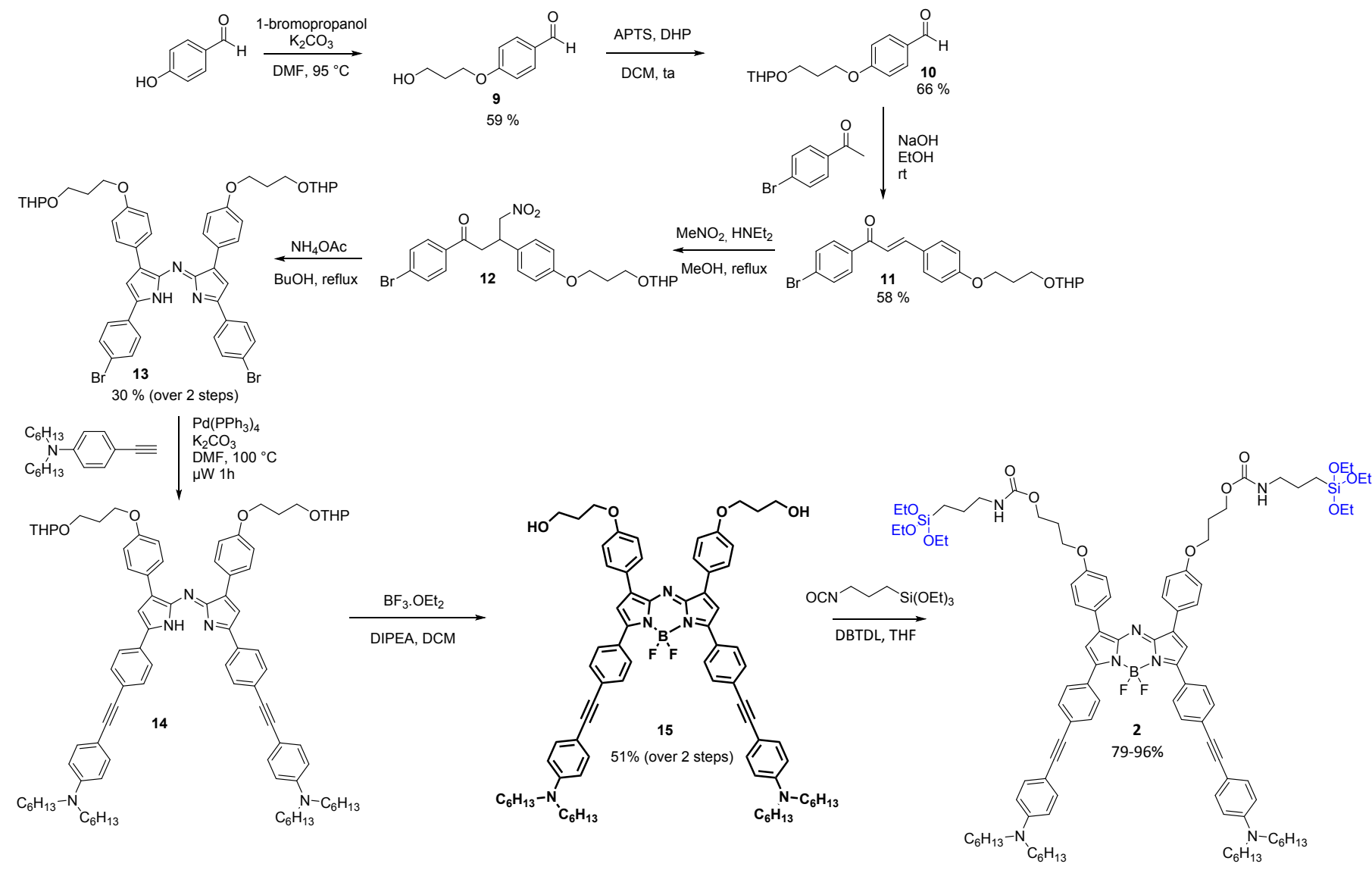

Scheme S2. Synthesis of compound 2.

2) Linear and nonlinear optical measurements.

Absorption and emission measurements. UV-visible spectra and transmittance spectra were recorded on a Jasco V-550 spectrophotometer in diluted solution ( $\mathrm{ca}$. 10 $0^{-6}$ mol.L $\left.\mathrm{L}^{-1}\right)$ using spectrophotometric grade solvents. UV-Vis-NIR transmittance spectra were recorded with a CARY 5G spectrophotometer.

The luminescence spectra were measured using a Horiba-Jobin Yvon Fluorolog-3® spectrofluorimeter, equipped with a three slits double grating excitation and emission monochromator with dispersions of $2.1 \mathrm{~nm} / \mathrm{mm}$ (1200 grooves $/ \mathrm{mm})$. The steady-state luminescence was excited by unpolarized light from a $450 \mathrm{~W}$ xenon continuous wave (CW) lamp and detected at an angle of $90^{\circ}$ for diluted solution measurements by a R928 detector (400-845 nm), a Peltier-cooled red-sensitive Hamamatsu R2658P photomultiplier tube (300$1010 \mathrm{~nm}$ ) and a liquid-nitrogen-cooled solid indium/gallium/arsenic NIR detector (850-1600 $\mathrm{nm})$. The spectra were corrected for both excitation-source light-intensity variation and emission spectral responses. Fluorescence lifetime was measured using TC-SPC Horiba 
apparatus; with Ludox in distilled water to determine the instrumental response function used for deconvolution. Excitation was performed using NanoLEDs. Luminescence quantum yields were measured in diluted solutions with an absorbance lower than 0.1 using the following equation $Q_{\mathrm{x}} / Q_{\mathrm{r}}=\left[A_{\mathrm{r}}(\lambda) / A_{\mathrm{x}}(\lambda)\right]\left[\mathrm{n}_{\mathrm{x}}^{2} / \mathrm{n}_{\mathrm{r}}^{2}\right]\left[D_{\mathrm{x}} / D_{\mathrm{r}}\right]$ were $A$ is the absorbance at the excitation wavelength $(\lambda), \mathrm{n}$ the refractive index and $D$ the integrated luminescence intensity. " $\mathrm{r}$ " and " $\mathrm{x}$ " stand for reference and sample. Excitation of reference and sample compounds was performed at the same wavelength.

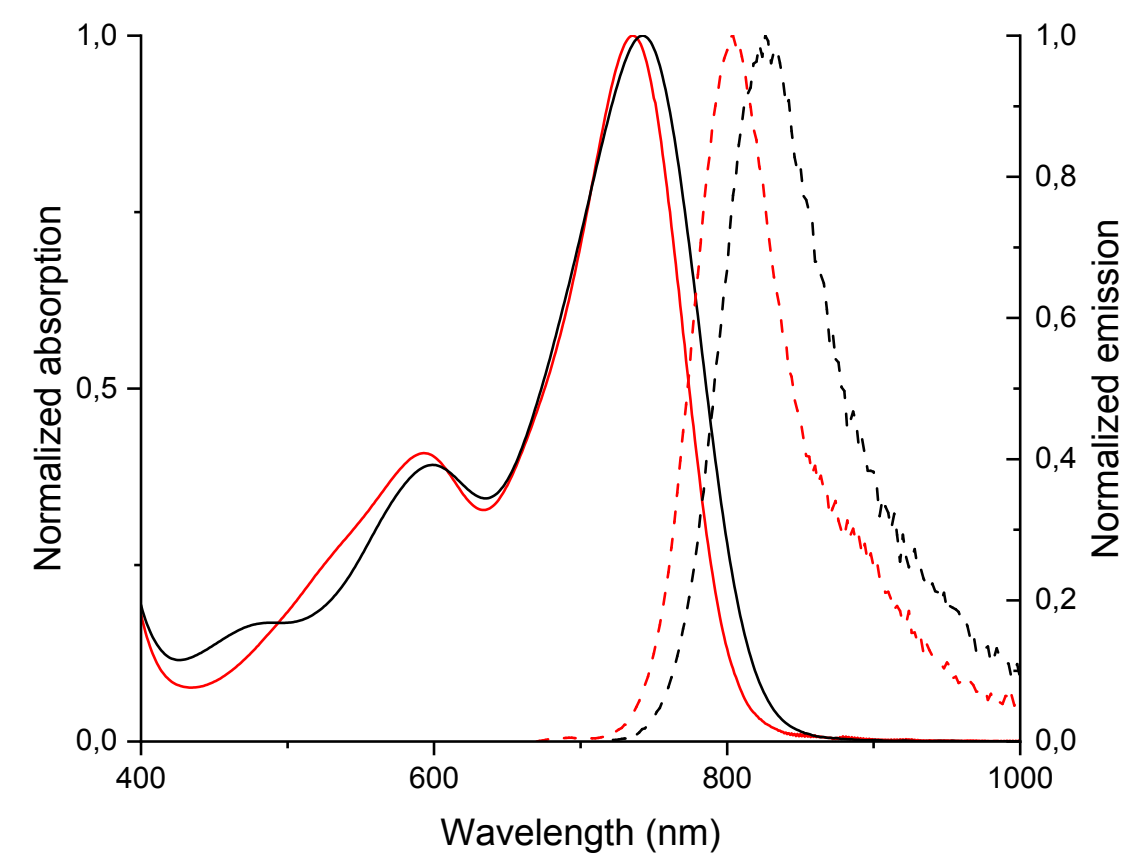

Figure S1. Comparison between the absorption and emission $\left(\lambda_{\mathrm{ex}}=635 \mathrm{~nm}\right)$ spectra of 3 black) and $\mathbf{1}$ (red) in toluene at room temperature.

Photochemical stability measurement. The photochemical stability of 1-4 in air-saturated DCM was quantitatively estimated using the absorption method described previously in detail. ${ }^{1}$ The values of photodecomposition quantum yields, $\Phi_{p h}$, were obtained for continuous wave (CW) diode laser irradiation of the sample solutions at $\approx 635 \mathrm{~nm}$ with the average irradiance $\approx 500 \mathrm{~mW} / \mathrm{cm}^{2}$.

Open aperture Z-scan measurements. The degenerate 2PA cross-sections of $\mathbf{3}$ was determined in DCM at room temperature by open aperture Z-scans ${ }^{2}$ using $1 \mathrm{~mm}$ path length quartz cuvettes with dyes concentrations $\mathrm{C} \sim 1-6 \times 10^{-3} \mathrm{M}$. Z-scan measurements were performed with a regeneratively amplified Ti:sapphire laser (Clark MXR, CPA 2010; exit wavelength, $775 \mathrm{~nm}$, 
pulse duration, $\tau_{P} \approx 150 \mathrm{fs}(\mathrm{FWHM})$, pulse energy, $E_{P} \approx 1 \mathrm{~mJ}$, and repetition rate $1 \mathrm{kHz}$ ) which pumped an optical parametric amplifier (OPA, Light Conversion, TOPAS C) with a tuning range from $1100 \mathrm{~nm}-2600 \mathrm{~nm}$ energies up to $\approx 0.25 \mathrm{~mJ}$. Focused spot sizes in the Zscan setup were calibrated using Z-scans on a GaAs plate at each wavelength and the output pulse durations of the 1PA were measured by the second-harmonic-generation autocorrelation technique. ${ }^{3}$
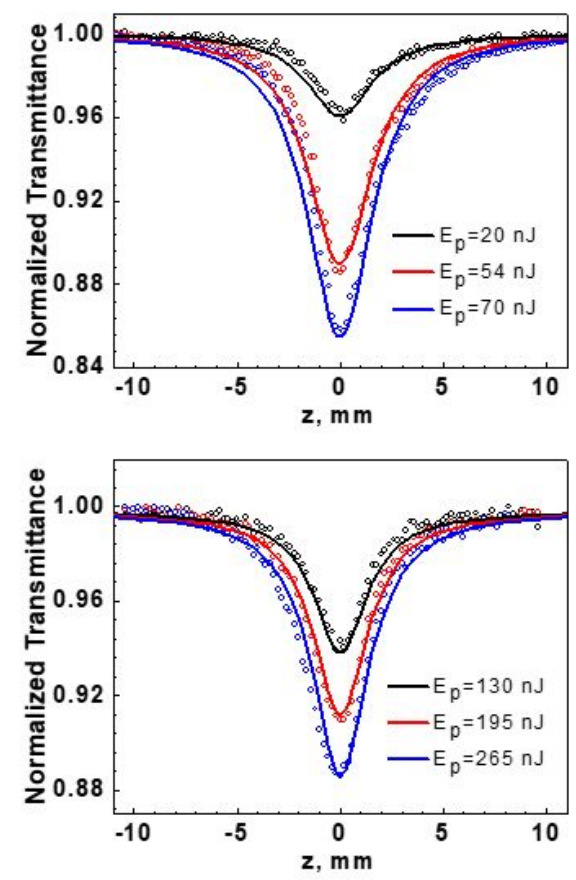

Figure S2. Open aperture Z-scans (separate points) and fittings curves (solid lines) for corresponding pulse energies, obtained for 3 in DCM at $1200 \mathrm{~nm}$ (top) and $1500 \mathrm{~nm}$ (bottom). 
Table S1. Nonlinear absorption coefficients of 3 in DCM: 2PA cross-section, $\sigma_{2 \mathrm{PA}}$, in GöppertMayer (GM); one-photon ESA cross-section, $\sigma_{\mathrm{ESA}}$ in $10^{-20} \mathrm{~m}^{2}$. (-) indicates that no ESA was use for the Z-scan fitting procedure.

\begin{tabular}{ccc}
\hline Wavelength $(\mathbf{n m})$ & $\boldsymbol{\sigma}_{\mathbf{2 P A}}(\mathbf{G M})$ & $\boldsymbol{\sigma}_{\mathrm{ESA}}\left(\mathbf{1 0}^{-\mathbf{2 0}} \mathbf{~ m}^{\mathbf{2}}\right)$ \\
\hline 1200 & $1900 \pm 200$ & $1.0 \pm 0.2$ \\
1300 & $1840 \pm 200$ & $0.96 \pm 0.06$ \\
1400 & $400 \pm 50$ & $0.14 \pm 0.03$ \\
1500 & $270 \pm 50$ & - \\
1550 & $320 \pm 50$ & $1.75 \pm 0.3$ \\
1700 & $200 \pm 40$ & - \\
\hline
\end{tabular}

\section{3) Computational details.}

Theoretical calculations have been performed using Density Functional Theory and its TimeDependent version (TD-DFT) on the structures displayed in Fig. S3. Except for the 2PA modelling, all calculations were performed with Gaussian16.A03. ${ }^{4}$ Given that the considered dyes obviously involve a series of charge-transfer states, we have chosen the CAM-B3LYP 5 range-separated hybrid functional for the calculations. The ground state geometries were optimized with the 6-31G(d) basis set, and analytical Hessian calculations have been systematically performed to ensure that the obtained structures are true minima of the potential energy surfaces. The 1PA transition energies and oscillator strengths were determined with TDDFT using the $6-311+G(2 d, p)$ atomic basis set and the same functional. This basis set combination for geometric and electronic parameters was previously demonstrated to be suited for aza-BODIPY derivatives. ${ }^{6}$ During geometry minimization and 1PA calculations, environmental effects were accounted for using the Polarizable Continuum Model (PCM), selecting, as in the experiment, dichloromethane as a solvent. In the 1PA calculation of the transition energies, we have here combined the results of the so-called linear-response (LR) ${ }^{7}$ and corrected-linear-response (cLR) ${ }^{8}$ models, following a procedure used earlier (so-called LR+cLR). ${ }^{9}$ In such a way, both the "linear-response" and "state-specific" solvation effects are accounted for during the 1PA calculations. In the main text, the excited states are represented by using electron density difference plots (EDD), in which the total electronic density of the ground state is subtracted from the one of the considered excited state. The plots (Figure 3 in the main text) use a contour threshold of $0.008 \mathrm{au}$, and the blue (red) lobes represent regions 
losing (gaining) densities upon photon absorption, i.e., donor (acceptor) moieties. From these EDD, the CT parameters were computed using Le Bahers' approach. ${ }^{10}$ For the $2 \mathrm{PA}$ crosssection we applied the very same CAM-B3LYP functional and the 6-31G atomic basis set using the response procedure implemented in the Dalton package; ${ }^{11}$ default parameters of this program have been applied.
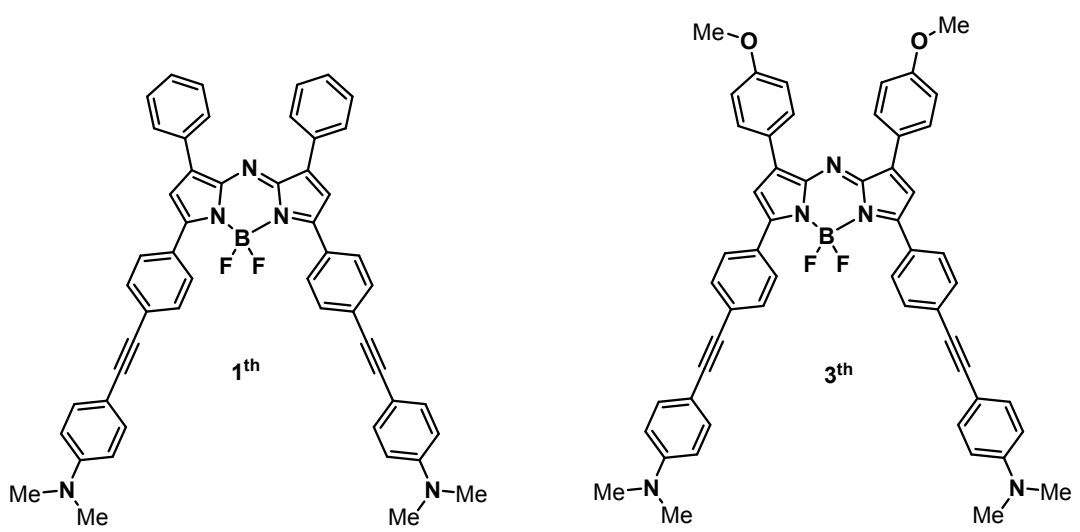

Figure S3. Structure of the simplified dyes $\mathbf{1}^{\text {th }}$ and $\mathbf{3}^{\text {th }}$ used for the calculations.

\section{4) Thermogravimetric analysis}

Thermal stability of compound $\mathbf{3}$ was evaluated by TGA analysis that were recorded on a NETZSCH STA $409 \mathrm{PC} / \mathrm{PG}$ under nitrogen atmosphere with a heating rate of $10^{\circ} \mathrm{C} / \mathrm{min}$ from $30{ }^{\circ} \mathrm{C}$ to $1000{ }^{\circ} \mathrm{C}$.

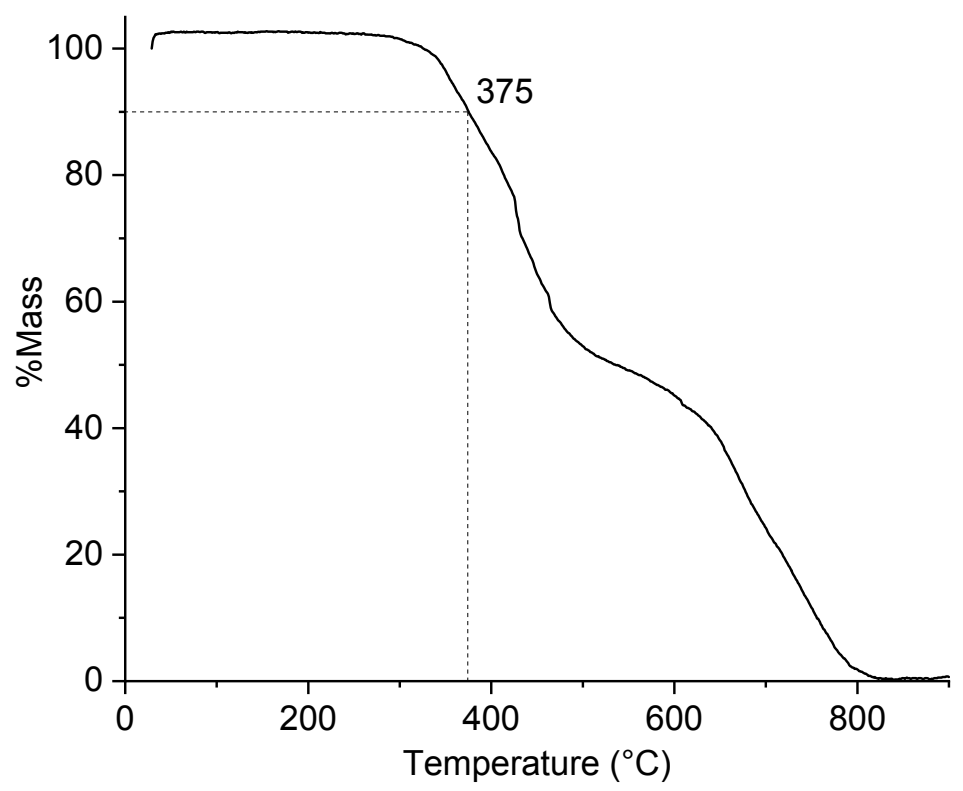

Figure S4. TGA analysis of compound 3 performed under $\mathrm{N}_{2}$ at $10{ }^{\circ} \mathrm{C} / \mathrm{min}$. 


\section{5) Materials preparation and characterization}

Sol and materials preparation. The sol used for the materials was obtained by controlled hydrolysis-condensation of an equimolar mixture of MTEOS (methyltriethoxysilane, $50 \mathrm{~mL}$ ) and VTMOS (vinyltrimethoxysilane, $38 \mathrm{~mL}$ ) by $100 \mathrm{ml}$ of citric acid $\left(15 \mathrm{~g} . \mathrm{L}^{-1}\right)$ in water at RT for $18 \mathrm{~h}$. After evaporation of the resulting alcohols on a rotating evaporator, the sol was extracted in diethylether $(150 \mathrm{~mL}$ ), washed 4 times with $30 \mathrm{~mL}$ water (the $\mathrm{pH}$ of after the last wash was tested to be $>4.5)$, and transferred into THF $(100 \mathrm{~mL})$ after evaporation under vacuum of the diethyl ether. The resulting sol in THF was concentrated to $45 \mathrm{wt} \%$ (measured by dry weight at $120^{\circ} \mathrm{C}$ ) to allow later addition of solvent for chromophore dissolution and was stored at $-30^{\circ} \mathrm{C}$. To prepare the materials, the appropriate amount of chromophore was dissolved in the minimum amount of THF in a PFA mold, after which the appropriate amounts of sol and additives ( $\mathrm{H}_{2} \mathrm{O}$ and VTMOS) were added, and completed by THF to get an approximate volume of $1 \mathrm{~mL}$. Then the gelation agents (DMATMS, TBAF 50mM solution) were added to the preparation. Details of preparation of each material are given in Table S2. The mold was closed and quickly stirred for at least $10 \mathrm{~s}$, then left undisturbed at RT until gelation was observed. Then, the mold was slightly opened (or the cap was replaced by a holed cap) and put in a $45^{\circ} \mathrm{C}$ ventilated oven for at least 2 days.

Note: for calculations, the amount of added VTMOS and DMATMS were taken into account as $53 \%$ and $67 \%$ of the weight respectively: this percentage corresponds to the resulting weight of those silanes after complete hydrolysis-condensation. The influence of TBAF was calculated as negligible (less than $1 \%$ of the weight of the chromophore) as well as solvents (water and THF)

Table S2. Preparation of the different sol-gel materials.

\begin{tabular}{ccccccc}
\hline Materials & Dye & $\begin{array}{c}\text { TBAF } \\
{[\boldsymbol{\mu L}]}\end{array}$ & $\begin{array}{c}\text { DMATMS } \\
{[\boldsymbol{\mu L}]}\end{array}$ & $\begin{array}{c}\text { VTMOS } \\
{[\boldsymbol{\mu L}]}\end{array}$ & $\begin{array}{c}\text { Water } \\
{[\boldsymbol{\mu L} \mathbf{L}}\end{array}$ & $\begin{array}{c}\text { Dye concentration } \\
{[\mathbf{w t} \%] /[\mathbf{m M}]}\end{array}$ \\
\hline Ref & 1 & 0 & 40 & 0 & 0 & $5 / 56$ \\
M10 & 3 & 20 & 20 & 35 & 10 & $10 / 70$ \\
M20 & 3 & 20 & 40 & 30 & 10 & $20 / 140$ \\
M40 & 3 & 45 & 45 & 50 & 15 & $40 / 280$ \\
M60 & 3 & 75 & 75 & 50 & 50 & $60 / 420$ \\
\hline
\end{tabular}


One material with a doping concentration of $20 \mathrm{w} \%$ was grinded and studied by ${ }^{29} \mathrm{Si}$ NMR. As it can be seen of Figure S5, the two main peaks observed in the ${ }^{29} \mathrm{Si}-\mathrm{NMR}$ spectrum correspond to fully condensed T3 peaks for alkylsiloxanes (methylsiloxane, dimethylaminopropylsiloxane, and siloxane of compound 2$)$ at $-65 \mathrm{ppm}$ and vinylsiloxane $(-80 \mathrm{ppm})$ respectively. The absence of T0 (uncondensed) or T1 (mono-condensed) alkylhydroxysiloxanes species is indicated by the lack of signals below -53 ppm and unambiguously proves the absence of uncondensed dye.<smiles>[R][Si](O)(O)O</smiles>

T0<smiles>[R][Si](O)(O)O[Si](C)(C)C</smiles>

T1<smiles>[R][Si](O)(O)O[Si](C)(C)C</smiles>

$\mathrm{T} 2$<smiles>[R][Si](O[Si](C)(C)C)(O[Si](C)(C)C)O[Si](C)(C)C</smiles>

T3

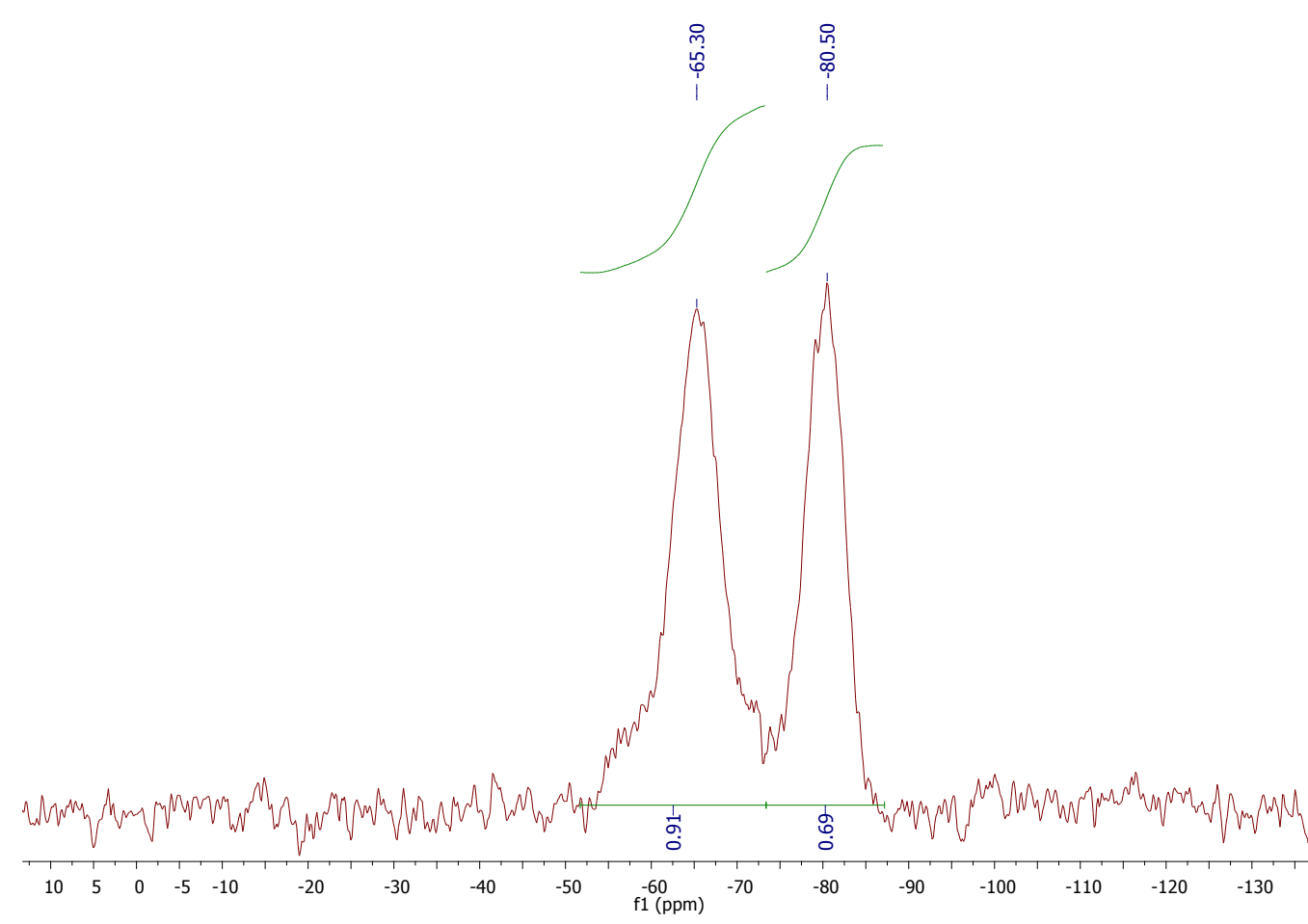

Figure S5. (Top) Schematic nomenclature of siloxane sites present in sol-gel material. (Bottom) Solid-state ${ }^{29} \mathrm{Si}$ NMR of a sol-gel material having a $40 \mathrm{w} \%$ doping concentration. The $\left\{{ }^{1} \mathrm{H}\right\}-$ ${ }^{29} \mathrm{Si}$ solid state RMN spectrum was recorded using Cross Polarization/Magic Angle Spinning (CP/MAS) on a Brucker Avance III 500MHz spectrometer equipped with a $4 \mathrm{~mm}$ double channel probe at $10 \mathrm{kHz}$ (96 scans and $300 \mathrm{~s}$ relaxation delay). 
IR imaging system. The "homemade" device used to investigate the homogeneity of the prepared xerogel is based on indirect diffuse lighting transmitted from an NIR emitting source through the samples and captured as pictures or videos by a simple CMOS sensor without the conventional NIR filter. As diffusive layer, a regular white paper over aluminum paper was used. This was applied inside an approximately $20 \times 25 \times 20 \mathrm{~cm}$ (width $\mathrm{x}$ length $\mathrm{x}$ height) cardboard box, with two holes $30 \mathrm{~mm}$ for observation, and $140 \mathrm{~mm}$ for the source (see Figure S3). The emitting source was a Phillips R95E NIR (100W) bulb (typical emission maximum around 1200-1400nm). For observation, a primary Zomei IR $95082 \mathrm{~mm}$ IR high-pass filter was used to remove all light below $950 \mathrm{~nm}$, surmounted by a manual iris aperture (1.5-23 mm 12 blades) to limit stray light and a second $1100 \mathrm{~nm}$ high-pass $25 \mathrm{~mm}$ filter from Thorlabs to enhance the visual transparency of the materials. To capture the footage, we used a $1080 \mathrm{p}$ camera based on a Omnivision OV2710 sensor and equipped with a 2.8-12 mm manual varifocal lens and a removable IR filter from ELP. All IR footages were processed in grayscale.

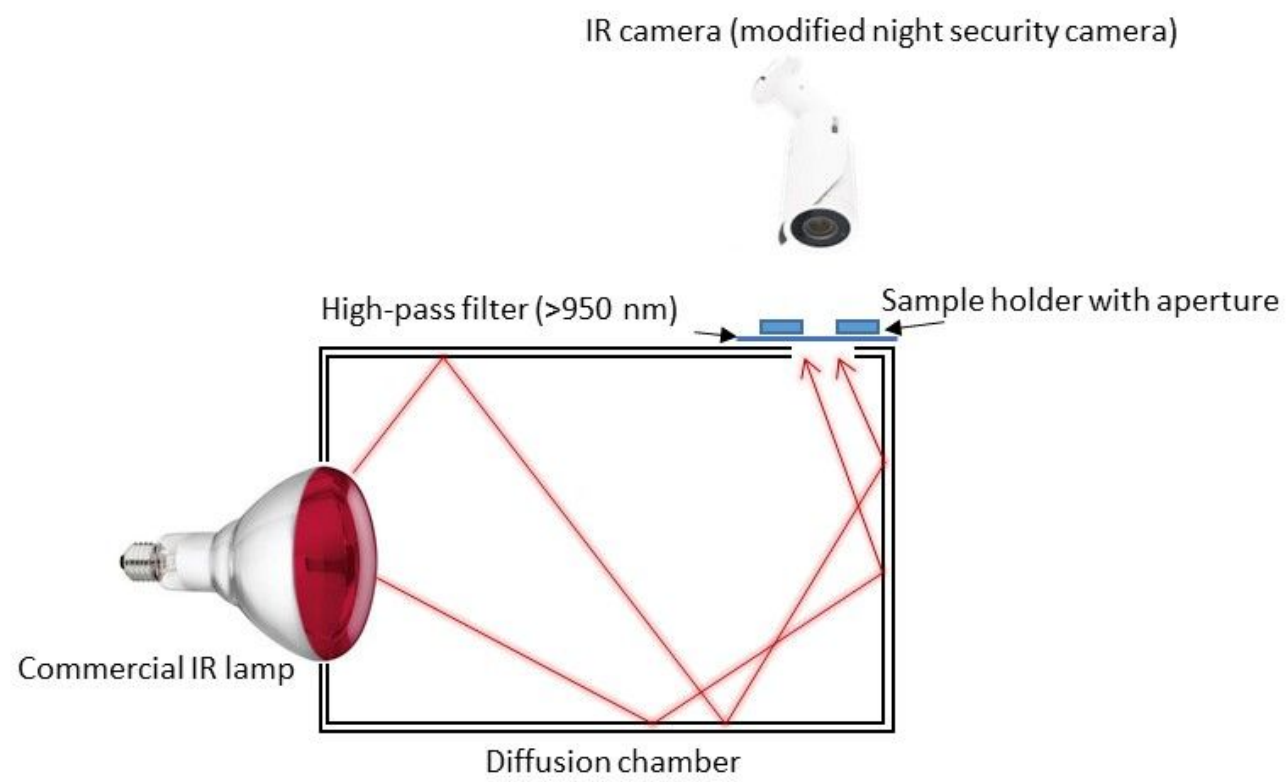

Figure S6. IR imaging set-up. 
without TBAF

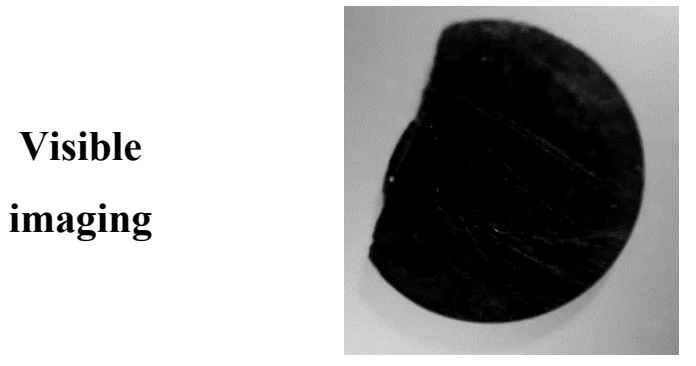

IR

imaging

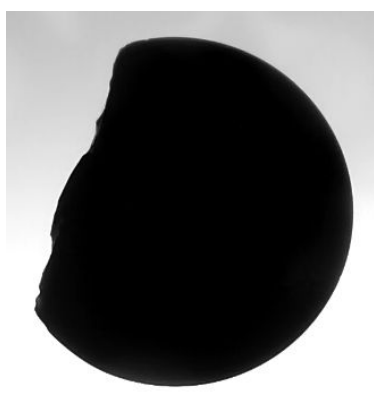

with TBAF
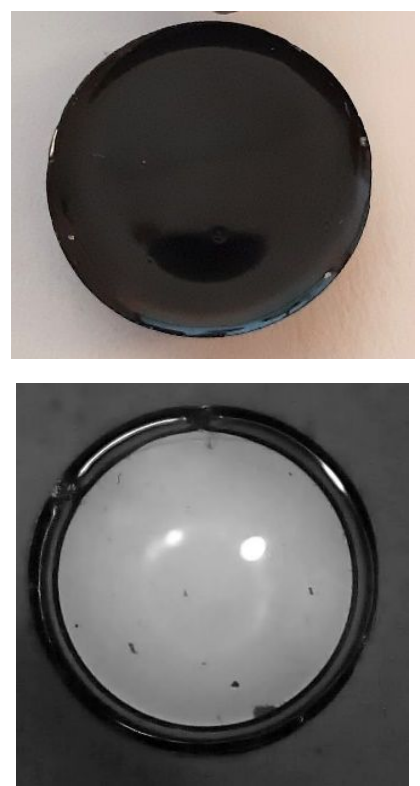

Figure S7. Comparison of the visible and NIR transparency and homogeneity of xerogels prepared with or without TBAF.

Study of maximal concentration reachable. It is worth noting that a last materials M60 has been prepared with a $60 \mathrm{wt} \%$ doping concentration of dye 2 (Table S1). This material however presented a total opacity on the whole spectral range. For the time being, the maximum doping concentration reachable with this method seems to be around $40 \mathrm{wt} \%$. However, the fact we have a totally opaque material for $\mathbf{M 6 0}$ and not a partial transmission loss might indicate that this preliminary experiment had suffered from a synthesis mistake. Other experiments are ongoing in our lab to try to overcome the $40 \mathrm{wt} \%$ doping concentration limit.

Materials polishing. Polishing of the materials was accomplished by the use of a Struers polishing equipment (Struers LaboPol-25). The final polished materials had a thickness of $1 \pm$ $0.05 \mathrm{~mm}$.

\section{6) Optical power limiting experiments.}

The OPL measurement set-up has been described earlier ${ }^{12}$ and is based on a f/5 system. The laser beam (source an EKSPLA NT342C OPO, (emitting 4 ns pulses) is expanded by a 3x Keplerian telescope. The beam passes through a pinhole filter with $25 \mu \mathrm{m}$ diameter, placed 
between two $\mathrm{f}=20 \mathrm{~cm}$ lenses, leading to a pellicle beam splitter that sends a small part of the pulse energy to the reference detector (Ophir PE9 laser energy meter). The remaining pulse energy is expanded by a 2.66x Keplerian telescope and passed through a $2 \mathrm{~cm}$ aperture creating an approximately top-hat beam. This approximately top-hat beam reaches a $2.5 \mathrm{x}$ Keplerian telescope that forms the $\mathrm{f} / 5$ system. A simple plano-spherical lens of focal length $1 \mathrm{~m}$ is used to focus the transmitted beam onto the signal pulse energy detector (Ophir PD10-V1-SH). The system is aligned at $1550 \mathrm{~nm}$ with the help of a digital video camera and a small aperture placed after the plano-spherical lens. Beam diameter is measured with the 10-90\% knife-edge method. The beam diameter varied between 16 and $19 \mu \mathrm{m}$ depending on the wavelength. It is worth noting that to avoid any transmission loss due to material damages induced by multiple laser shots on the same spot, studied xerogels were slightly moved perpendicular to the beam direction between each laser pulses.

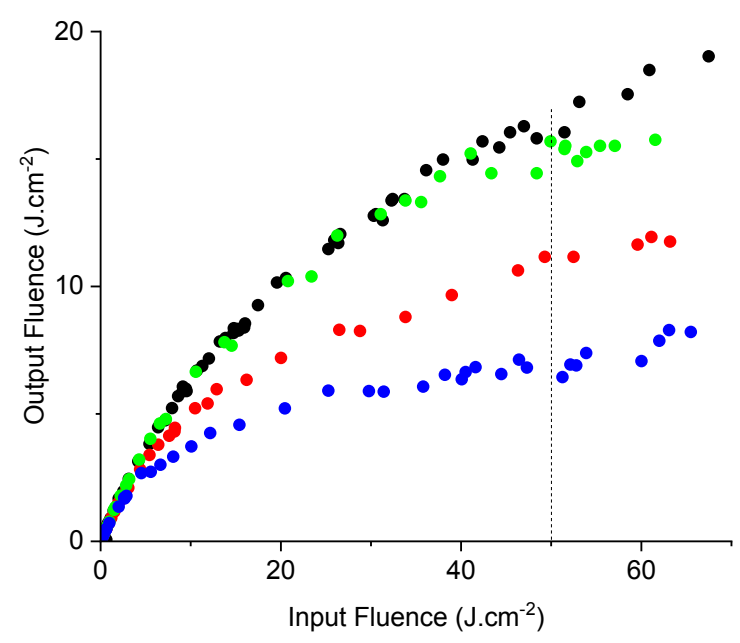

Figure S8. Alternative to Figure 5. Optical limiting performances at $1550 \mathrm{~nm}$ for materials $\operatorname{M10}(\bullet), \operatorname{M20}(\bullet), \operatorname{M40}(\bullet)$. For comparison, the reference doped material $\operatorname{MRef}(\bullet)$ was measured under the same conditions. The output energy has been divided by the beam size at focus.

\section{7) Synthetic protocols and characterization.}

General. NMR spectra $\left({ }^{1} \mathrm{H},{ }^{13} \mathrm{C}\right)$ were recorded at room temperature on a Bruker AVANCE 300 operating at $300.13 \mathrm{MHz}, 96 \mathrm{MHz}$ and 282.40 for ${ }^{1} \mathrm{H},{ }^{11} \mathrm{~B}$ and ${ }^{19} \mathrm{~F}$ respectively and on a Bruker AVANCE 400 operating at 400.14 MHZ and 100.62 MHz for ${ }^{1} \mathrm{H}$ and ${ }^{13} \mathrm{C}$, respectively. Data are listed in parts per million (ppm) and are reported relative to tetramethylsilane $\left({ }^{1} \mathrm{H}\right.$, $\left.{ }^{13} \mathrm{C}\right)$, residual solvent peaks being used as internal standard $\left(\mathrm{CHCl}_{3}{ }^{1} \mathrm{H}: 7.26 \mathrm{ppm},{ }^{13} \mathrm{C}: 77.16\right.$ ppm). ${ }^{1} \mathrm{H}$ NMR patterns are designated as singlet (s), doublet (d), triplet (t), quartet (q), quintet 
(quint), multiplet (m), broad (br). High resolution mass spectrometry measurements were performed at the Centre Commun de Spectrométrie de Masse (Université Claude Bernard Lyon 1) with a ESI-QTOF (Bruker Daltonics MicroTOF-Q II). 4-ethynyl-N,N-dihexylaniline, compound $\mathbf{1}$, were prepared according to published procedures. ${ }^{13}$

\section{Synthesis}

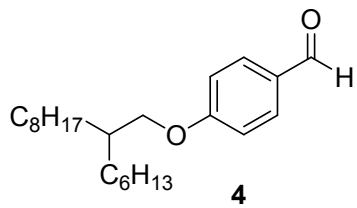

Compound 4. To a solution of 4-hydroxybenzaldehyde (0.929 g, 7.604 mmol, 1 equiv.) in DMF (12 mL) was added 1-bromo-2-hexyldecanol (2.554 g, 8.364 mmol, 1.1 equiv.), followed by potassium carbonate ( $1.261 \mathrm{~g}, 9.125 \mathrm{mmol}, 1.2$ equiv.). The mixture was stirred at $80^{\circ} \mathrm{C}$ overnight. After cooling down to RT, water and PE were added. The organic layer was collected, washed with brine and dried over $\mathrm{Na}_{2} \mathrm{SO}_{4}$. Solvent was evaporated under reduced pressure. The product was obtained as a pale yellow oil (2.569 g, $97 \%)$. ${ }^{1} \mathrm{H}$ NMR (300 $\left.\mathrm{MHz}, \mathrm{CDCl}_{3}\right) \delta 9.88(\mathrm{~s}, 1 \mathrm{H}), 7.83(\mathrm{~d}, J=8.7 \mathrm{~Hz}, 2 \mathrm{H}), 6.99(\mathrm{~d}, J=8.7 \mathrm{~Hz}, 2 \mathrm{H}), 3.91$ (d, $J=$ $5.7 \mathrm{~Hz}, 2 \mathrm{H}), 1.84-1.75(\mathrm{~m}, 1 \mathrm{H}), 1.49-1.17(\mathrm{~m}, 24 \mathrm{H}), 0.88(\mathrm{t}, J=6.1 \mathrm{~Hz}, 6 \mathrm{H})$.

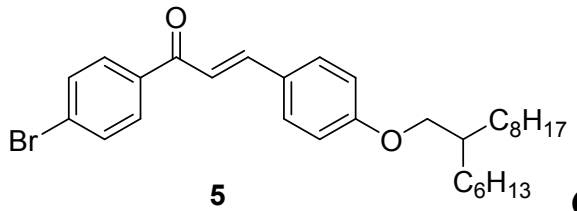

Compound 5. Aldehyde 4 (7.808 g, 22.53 mmol, 1 equiv.) and 4-bromoacetophenone (4.933 g, $24.78 \mathrm{mmol}, 1.1$ equiv.) were dissolved in ethanol (90 $\mathrm{mL})$. Sodium hydroxide $2.5 \mathrm{M}(90 \mathrm{~mL})$ was added dropwise at $0{ }^{\circ} \mathrm{C}$ and the solution was stirred at RT overnight. As there was no precipitation, the reaction mixture was extracted with EtOAc, and combined organic layers washed with water and brine. The crude yellow oil was purified by column chromatography with PE/EtOAc 95:5 - 9:1 as eluent. The product (yellow oil, 8.1 g) was immediately used for the next step. ${ }^{1} \mathrm{H}$ NMR $\left(300 \mathrm{MHz}, \mathrm{CDCl}_{3}\right) \delta 7.90-7.85(\mathrm{~m}, 2 \mathrm{H})$, $7.79(\mathrm{~d}, J=15.6 \mathrm{~Hz}, 1 \mathrm{H}), 7.67-7.62$ (m, 2H), 7.59 (d, $J=8.7 \mathrm{~Hz}, 2 \mathrm{H}), 7.34$ (d, $J=15.6 \mathrm{~Hz}$, $1 \mathrm{H}), 6.93(\mathrm{~d}, J=8.7 \mathrm{~Hz}, 2 \mathrm{H}), 3.88(\mathrm{~d}, J=5.7 \mathrm{~Hz}, 2 \mathrm{H}), 1.86-1.71(\mathrm{~m}, 1 \mathrm{H}), 1.48-1.20(\mathrm{~m}$, $24 \mathrm{H}), 0.95-0.79(\mathrm{~m}, 6 \mathrm{H})$. 
<smiles>CCC(C)CC(CC(=O)c1ccc(Br)cc1)c1ccc(OCC(CC)CC)cc1</smiles>

Compound 6. Chalcone 5 was dissolved in methanol (110 $\mathrm{mL})$. Diethylamine (5.61 g, $76.76 \mathrm{mmol}, 7.9 \mathrm{~mL}, 5$ equiv.) and nitromethane (4.69 g, 76.76 mmol, $4.1 \mathrm{~mL}, 5$ equiv.) were then added. The solution was refluxed overnight. After cooling down to RT, the reaction was quenched with an aqueous solution of hydrochloric acid (2.5 M) until $\mathrm{pH}=2-3$. The solution was extracted with ethyl acetate and the recombined organic layers were washed with brine and dried over sodium sulfate. The solvent was evaporated and the crude brown oil $(8.166 \mathrm{~g})$ was used without further purification. ${ }^{1} \mathrm{H} \mathrm{NMR}\left(300 \mathrm{MHz}, \mathrm{CDCl}_{3}\right) \delta$ $7.77(\mathrm{~d}, J=8.6 \mathrm{~Hz}, 2 \mathrm{H}), 7.60(\mathrm{~d}, J=8.6 \mathrm{~Hz}, 2 \mathrm{H}), 7.16(\mathrm{~d}, J=8.6 \mathrm{~Hz}, 2 \mathrm{H}), 6.84(\mathrm{~d}, J=8.6 \mathrm{~Hz}$, 2H), $4.77(\mathrm{dd}, J=12.4,7.0 \mathrm{~Hz}, 1 \mathrm{H}), 4.64(\mathrm{dd}, J=12.4,7.6 \mathrm{~Hz}, 1 \mathrm{H}), 4.19-4.08(\mathrm{~m}, 1 \mathrm{H}), 3.78$ $(\mathrm{d}, J=5.7 \mathrm{~Hz}, 2 \mathrm{H}), 3.38(\mathrm{~d}, J=7.4 \mathrm{~Hz}, 2 \mathrm{H}), 1.81-1.65(\mathrm{~m}, 1 \mathrm{H}), 1.45-1.18(\mathrm{~m}, 24 \mathrm{H}), 0.87(\mathrm{t}$, $J=6.6 \mathrm{~Hz}, 6 \mathrm{H})$.

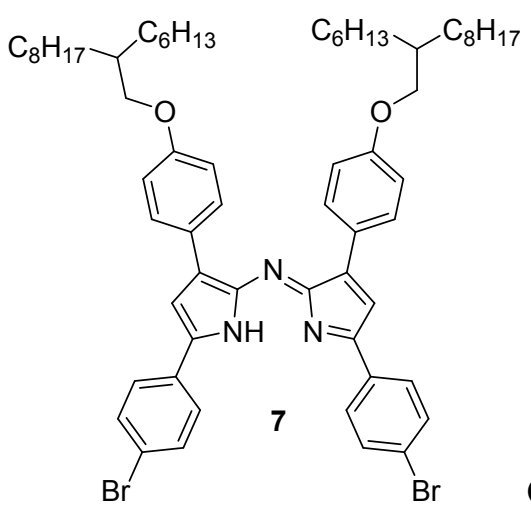

Compound 7. Compound 6 (8.166 g, 13.87 mmol, 1 equiv.) was dissolved in butanol (125 mL). Ammonium acetate (approx. $37 \mathrm{~g}$, approx. $486 \mathrm{mmol}$, approx. 35 equiv.) was then added to the reaction mixture. The resulting solution was heated under reflux during $18 \mathrm{~h}$. The reaction was then cooled down to RT. The solvent was concentrated to half and the crude filtered. The isolated solid was washed thoroughly with cold ethanol to give the desired product as a black powder (2.593 g, 21\% over 3 steps). ${ }^{1} \mathrm{H}$ NMR $\left(400 \mathrm{MHz}, \mathrm{CDCl}_{3}\right) \delta 7.94-7.91(\mathrm{~m}, 4 \mathrm{H}), 7.64(\mathrm{~d}, J=8.6 \mathrm{~Hz}, 4 \mathrm{H}), 7.55(\mathrm{~d}, J=8.6 \mathrm{~Hz}, 4 \mathrm{H})$, $6.95(\mathrm{~s}, 2 \mathrm{H}), 6.92(\mathrm{~d}, J=8.9 \mathrm{~Hz}, 4 \mathrm{H}), 3.91(\mathrm{~d}, J=5.7 \mathrm{~Hz}, 4 \mathrm{H}), 1.91-1.73(\mathrm{~m}, 2 \mathrm{H}), 1.54-1.24$ (m, 48H), $0.94-0.81(\mathrm{~m}, 12 \mathrm{H}) .{ }^{13} \mathrm{C} \mathrm{NMR}\left(101 \mathrm{MHz}, \mathrm{CDCl}_{3}\right) \delta$ 159.86, 153.88, 149.79, 142.70, $132.34,131.24,130.41,127.84,126.26,124.19,114.51,113.32,71.21,38.20,32.08,32.05$, $31.54,30.24,29.90,29.80,29.53,27.06,27.02,22.85,14.28$. HRMS $\left(\mathrm{ESI}^{+}\right)$calcd. for $[\mathrm{M}+\mathrm{H}]^{+}$: 1086.5081. Found: 1086.5103. 


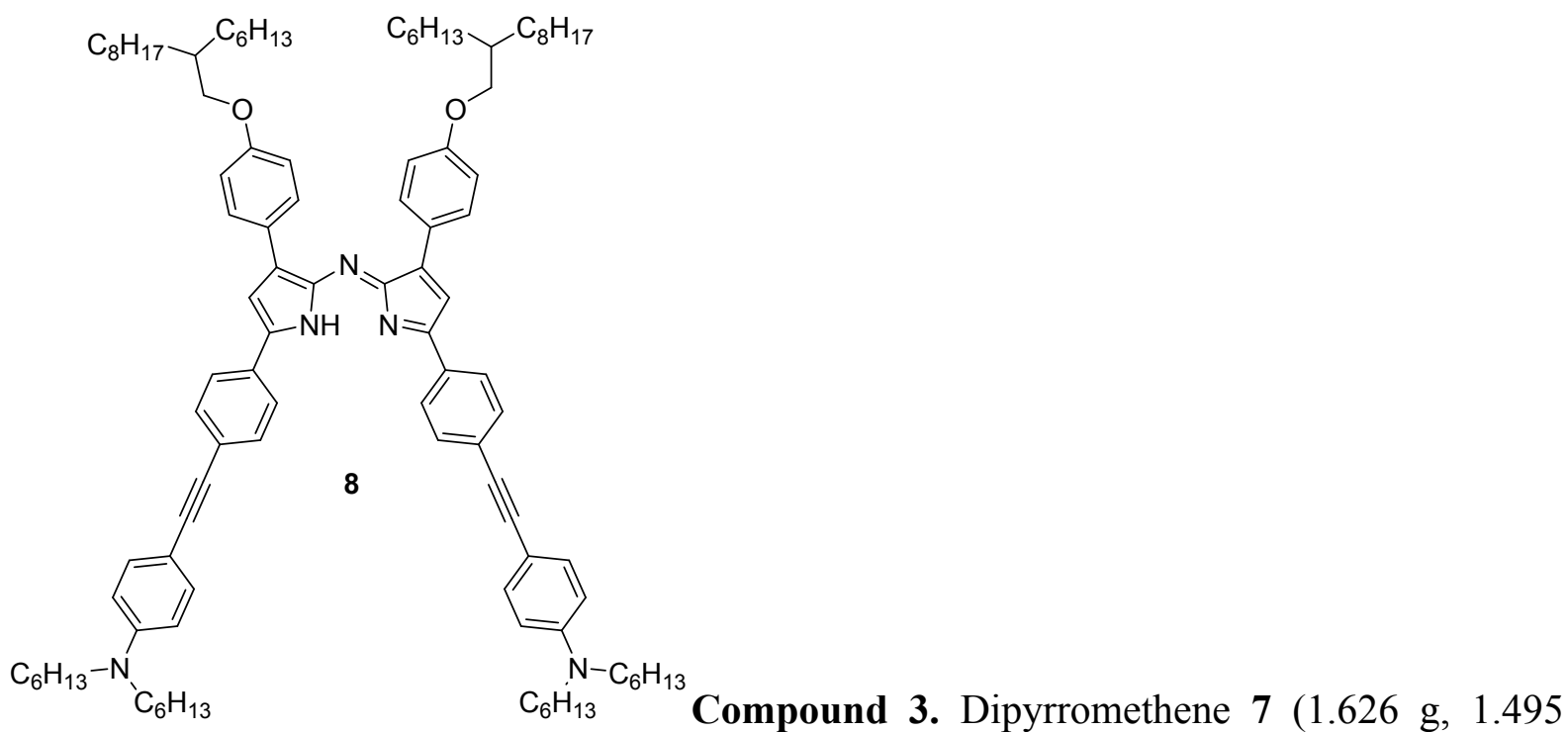

mmol, 1 equiv.), 4-ethynyl-N,N-dihexylaniline (0.896 g, $3.193 \mathrm{mmol}, 2.1$ equiv.), potassium carbonate $(0.826 \mathrm{mg}, 5.98 \mathrm{mmol}, 4$ equiv.) were dissolved in DMF (40 mL). The mixture was degassed 3 times by freeze-pump-thaw. $\mathrm{Pd}\left(\mathrm{PPh}_{3}\right)_{4}(173 \mathrm{mg}, 0.150 \mathrm{mmol}, 10 \mathrm{~mol} \%)$ was then added and the mixture stirred under argon at $100{ }^{\circ} \mathrm{C}$ overnight. The mixture was filtered over celite, eluted with DCM and washed several times with ammonium chloride, water and brine. The organic layer was dried over sodium sulfate and evaporated under reduced pressure. The crude product was triturated in $\mathrm{EtOH}$ to remove excess alkyne. The crude product 8 (black wax) was directly used for the next step. ${ }^{1} \mathrm{H}$ NMR $\left(300 \mathrm{MHz}, \mathrm{CDCl}_{3}\right) \delta 8.03(\mathrm{~d}, J=8.8 \mathrm{~Hz}, 4 \mathrm{H}), 7.90$ $(\mathrm{d}, J=8.4 \mathrm{~Hz}, 4 \mathrm{H}), 7.63(\mathrm{~d}, J=8.4 \mathrm{~Hz}, 4 \mathrm{H}), 7.41(\mathrm{~d}, J=8.9 \mathrm{~Hz}, 4 \mathrm{H}), 7.12(\mathrm{~s}, 2 \mathrm{H}), 6.97(\mathrm{~d}, J=$ $8.8 \mathrm{~Hz}, 4 \mathrm{H}), 6.60$ (d, $J=8.9 \mathrm{~Hz}, 4 \mathrm{H}), 3.91$ (d, $J=5.6 \mathrm{~Hz}, 4 \mathrm{H}), 3.34-3.23(\mathrm{~m}, 8 \mathrm{H}), 1.84$ (s, $2 \mathrm{H}), 1.65-1.19(\mathrm{~m}, 80 \mathrm{H}), 0.98-0.77(\mathrm{~m}, 24 \mathrm{H})$.

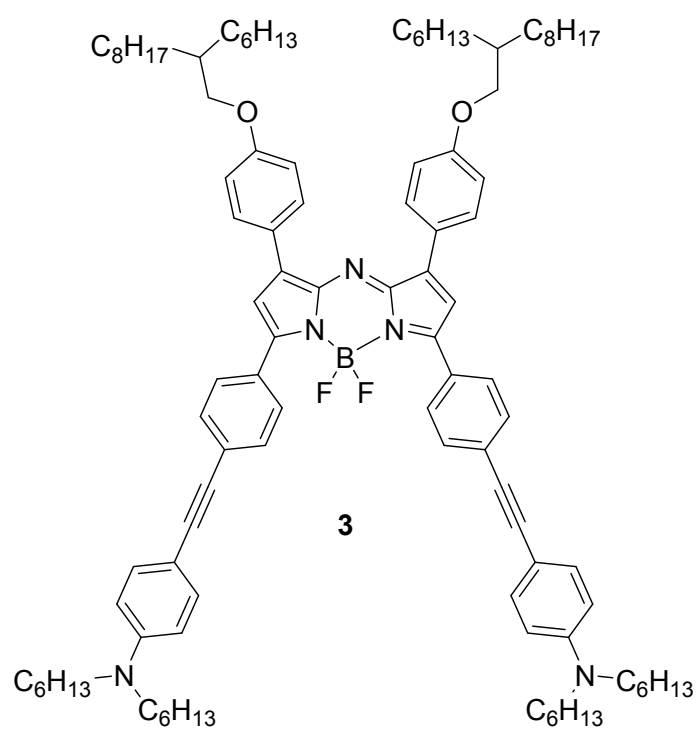


Crude dipyrromethene 8 (2.24 g, 1.495 mmol, 1 equiv.) was dissolved in DCM (120 mL). Diisopropylethylamine (DIPEA) (1.932 mg, $14.95 \mathrm{mmol}, 2.6 \mathrm{~mL}, 10$ equiv.) was added dropwise. The solution was stirred at RT for 20 min then $\mathrm{BF}_{3} . \mathrm{OEt}_{2}(3.183 \mathrm{~g}, 22.425 \mathrm{mmol}, 2.8$ $\mathrm{mL}, 15$ equiv.) was added. The solution was stirred at RT under argon overnight and the solution was washed with a saturated aqueous ammonium chloride solution, water and brine. The organic layer was dried over sodium sulfate and the solvent was evaporated. The crude product was purified by column chromatography on silica using DCM/Cyclohexane gradient 3:7 to 5:5 as eluent. Product 3: dark blue wax (1.386 g, 60\% over two steps). ${ }^{1} \mathrm{H}$ NMR (400 $\mathrm{MHz}, \mathrm{CDCl}_{3}$ ) $\delta 8.10-8.03(\mathrm{~m}, 8 \mathrm{H}), 7.57(\mathrm{~d}, J=8.5 \mathrm{~Hz}, 4 \mathrm{H}), 7.39(\mathrm{~d}, J=8.8 \mathrm{~Hz}, 4 \mathrm{H}), 7.00(\mathrm{~d}, J=8.5 \mathrm{~Hz}$, $6 \mathrm{H}), 6.58(\mathrm{~d}, J=9.0 \mathrm{~Hz}, 4 \mathrm{H}), 3.93(\mathrm{~d}, J=5.7 \mathrm{~Hz}, 4 \mathrm{H}), 3.33-3.25(\mathrm{~m}, 8 \mathrm{H}), 1.92-1.82(\mathrm{~m}$, 2H), $1.68-1.59(\mathrm{~m}, 8 \mathrm{H}), 1.53-1.23(\mathrm{~m}, 72 \mathrm{H}), 0.95-0.82(\mathrm{~m}, 24 \mathrm{H}) .{ }^{13} \mathrm{C}$ NMR $(101 \mathrm{MHz}$, $\left.\mathrm{CDCl}_{3}\right) \delta 160.80,157.73,148.19,145.77,143.35,133.16,131.24,130.81,130.30,129.50$, 126.96, 125.15, 117.47, 114.79, 111.22, 108.46, 94.56, 87.81, 71.15, 51.00, 38.01, 31.92, 31.87, $31.72,31.37,30.05,29.70,29.61,29.36,27.21,26.92,26.88,26.81,22.69,14.12,14.05 .{ }^{19} \mathrm{~F}$ NMR $\left(282 \mathrm{MHz}, \mathrm{CDCl}_{3}\right) \delta-130.91$ (q, $J=31.8 \mathrm{~Hz}$ ). HRMS $\left(\mathrm{ESI}^{+}\right)$calcd. for $[\mathrm{M}+\mathrm{H}]^{+}$: 1545.1454. Found: 1545.1514.

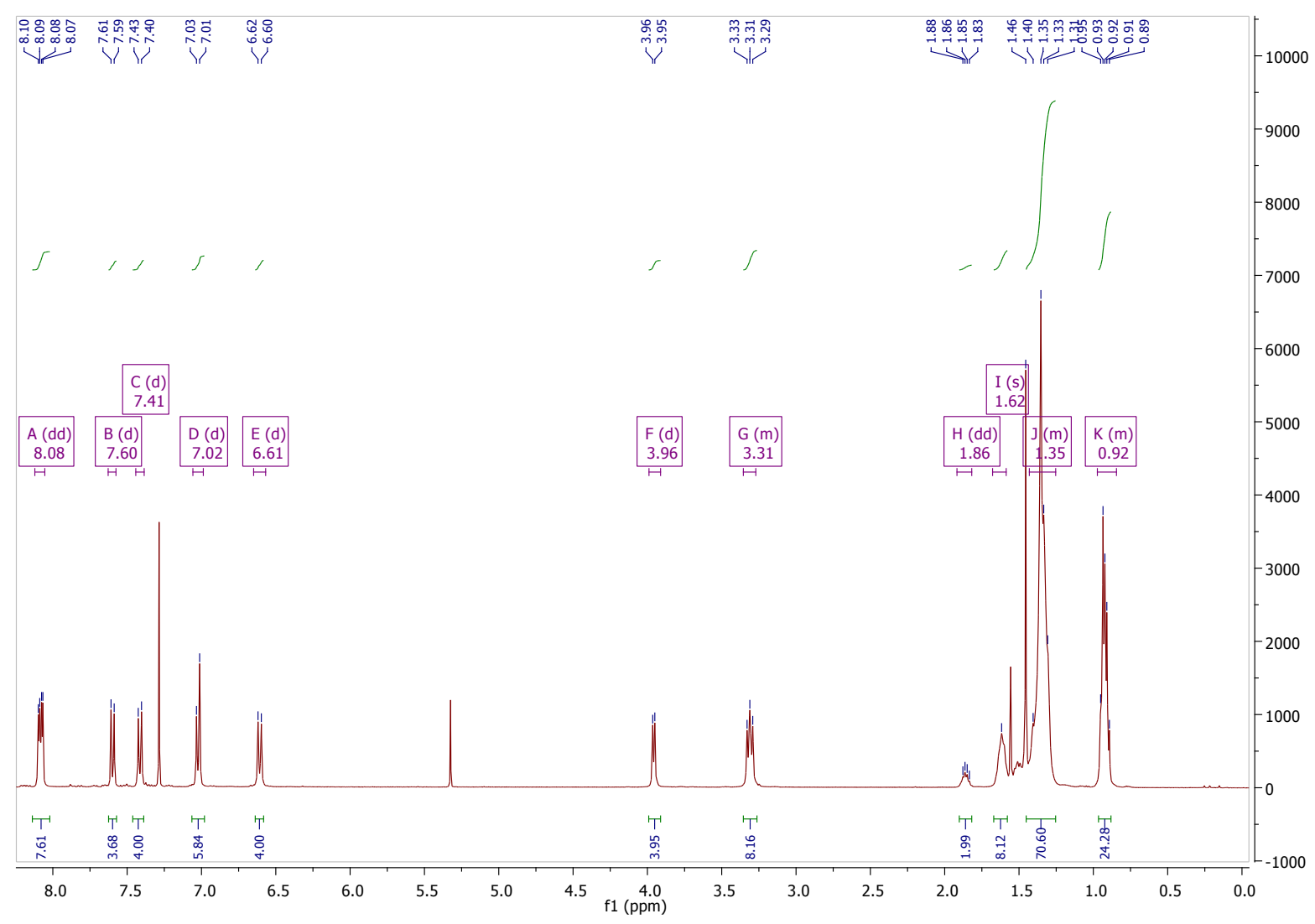

Figure S9. ${ }^{1} \mathrm{H} \mathrm{NMR}$ spectrum $\left(\mathrm{CDCl}_{3}\right)$ of compound $\mathbf{3}$ 


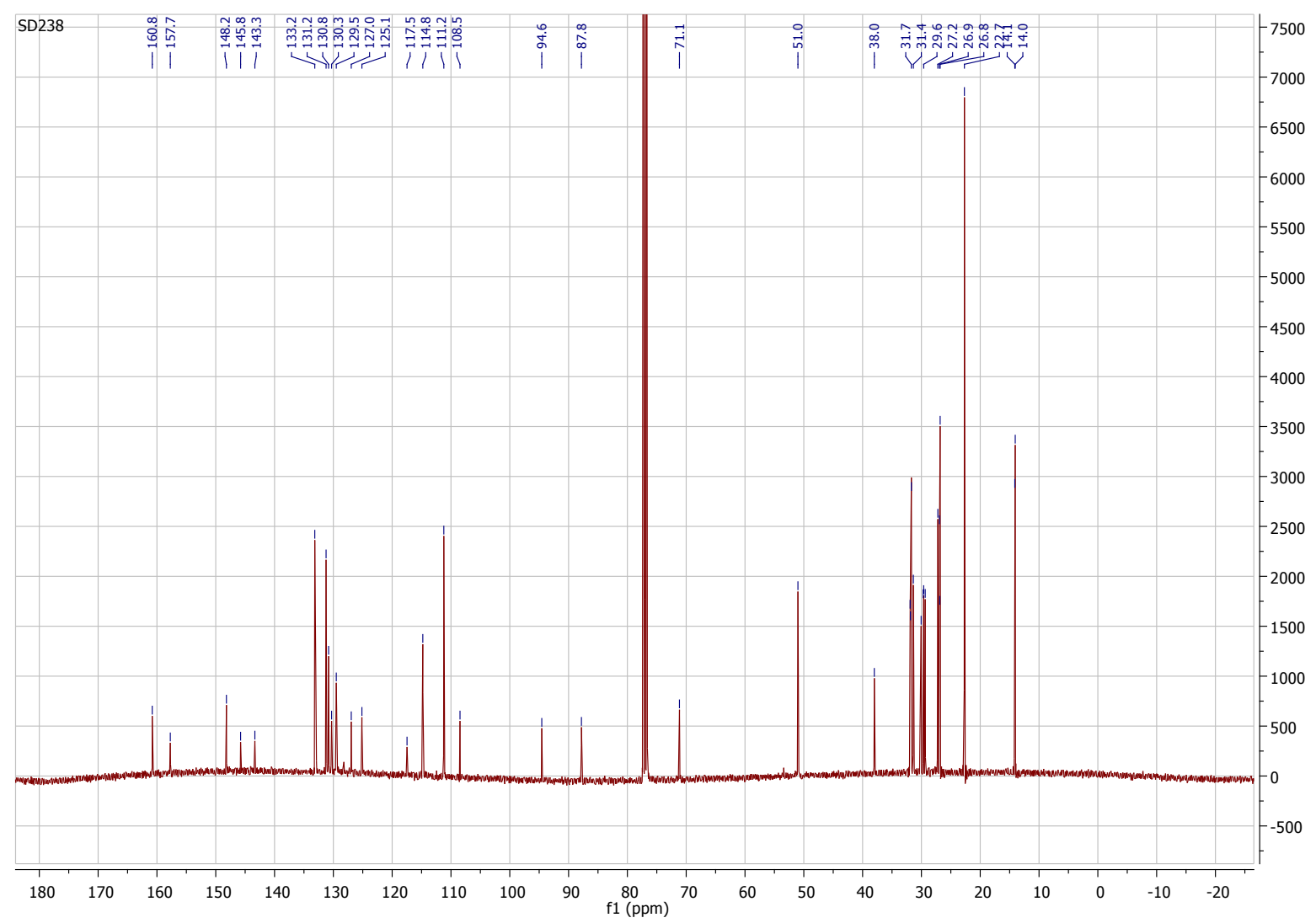

Figure S10. ${ }^{13} \mathrm{C}$ NMR spectrum $\left(\mathrm{CDCl}_{3}\right)$ of compound 3

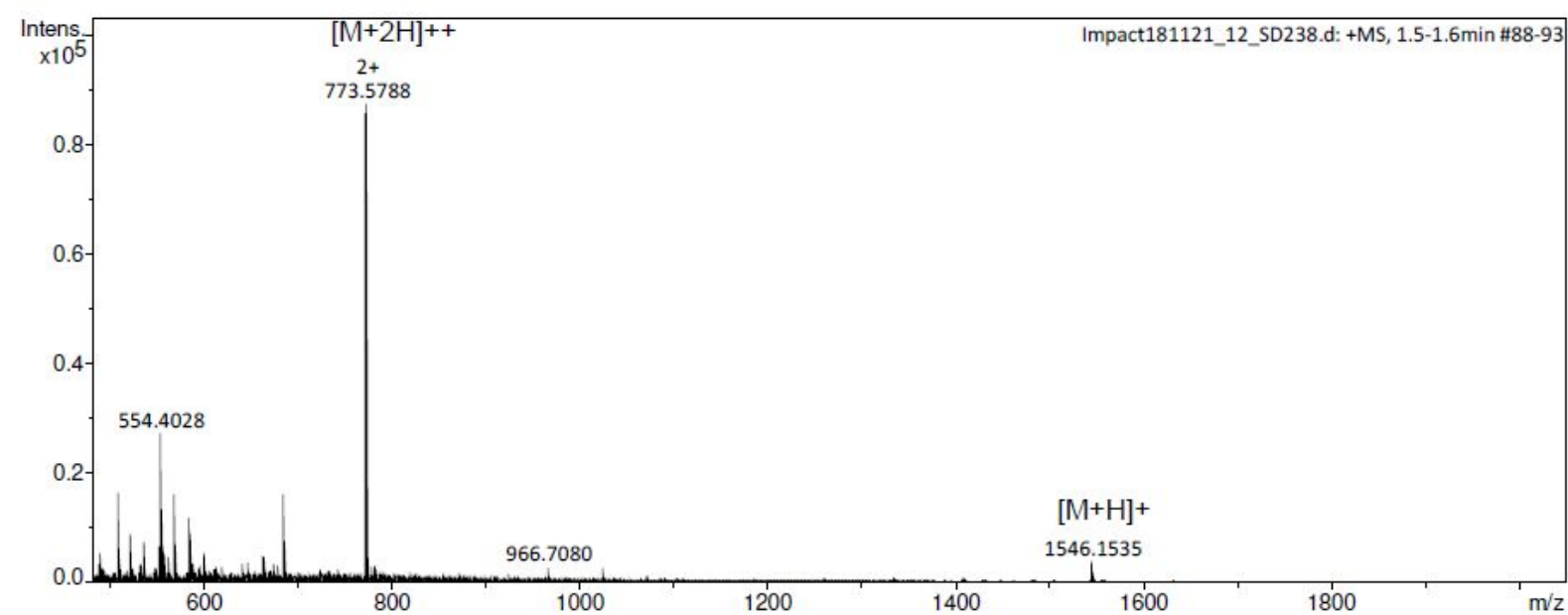

$\begin{array}{rlrrr}\text { Meas. } \mathbf{~} / \mathbf{z} & \text { lon Formula } & \mathbf{m} / \mathbf{z} & \text { err [ppm] } & \text { mSigma } \\ 773.0775 & \text { C104H146BF2N5O2 } & 773.0763 & -0.5 & 11.9 \\ 1545.1514 & \text { C104H145BF2N5O2 } & 1545.1454 & -2.9 & 144.1\end{array}$

Figure S11. HRMS spectrum of compound 3 


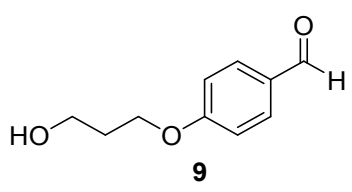

Compound 9. To a solution of 4-hydroxybenzaldehyde (4.00 g, $32.75 \mathrm{mmol}, 1$ equiv.) in DMF (30 mL) was added 3-bromo-1-propanol (4.973 g, $36.03 \mathrm{mmol}$, 1.1 equiv), followed by potassium carbonate ( $5.43 \mathrm{~g}, 39.3 \mathrm{mmol}, 1.2$ equiv.). The mixture was stirred at $80^{\circ} \mathrm{C}$ for 2 days. After cooling down to RT, water and PE were added. The organic layer was collected, washed with brine and dried over $\mathrm{Na}_{2} \mathrm{SO}_{4}$. Solvent was evaporated under reduced pressure. The product was purified by column chromatography using EP/EtOAc 1:1 as eluent. Product: yellowish oil (3.453 g, 59\%.). ${ }^{1} \mathrm{H}$ NMR (300 MHz, $\left.\mathrm{CDCl}_{3}\right) \delta 9.88(\mathrm{~s}, 1 \mathrm{H}), 7.83$ $(\mathrm{d}, J=8.8 \mathrm{~Hz}, 2 \mathrm{H}), 7.01(\mathrm{~d}, J=8.7 \mathrm{~Hz}, 2 \mathrm{H}), 4.21(\mathrm{t}, J=6.1 \mathrm{~Hz}, 2 \mathrm{H}), 3.88(\mathrm{t}, J=5.9 \mathrm{~Hz}, 2 \mathrm{H})$, $2.13-2.03(\mathrm{~m}, 2 \mathrm{H})$. NMR data in agreement with the literature. ${ }^{14}$

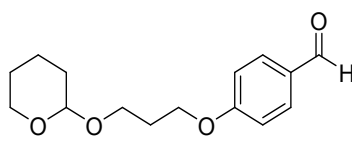

Compound 10. To a solution of 9 (8.011 g, $44.45 \mathrm{mmol}, 1$ equiv) in DCM (125 mL) was added APTS monohydrate $(0.169 \mathrm{~g}, 0.889 \mathrm{mmol}, 2 \mathrm{~mol} \%)$ and DHP (4.488 g, $53.35 \mathrm{mmol}, 1.2$ equiv). The resulting mixture was stirred at RT overnight. The reaction was quenched with water, extracted with DCM; The organic layers were combined and washed with brine, dried over sodium sulfate and evaporated. The crude was purified by column chromatography using EP/EtOAc 7:3 to 1:1 gradient as eluent. Product: 7.711 g, 66\%. ${ }^{1} \mathrm{H}$ NMR $\left(400 \mathrm{MHz}, \mathrm{CDCl}_{3}\right) \delta 9.86(\mathrm{~s}, 1 \mathrm{H}), 7.81(\mathrm{~d}, J=8.7 \mathrm{~Hz}, 2 \mathrm{H}), 6.99(\mathrm{~d}, J=8.7 \mathrm{~Hz}, 2 \mathrm{H}), 4.61-$ $4.56(\mathrm{~m}, 1 \mathrm{H}), 4.16(\mathrm{t}, J=6.3 \mathrm{~Hz}, 2 \mathrm{H}), 3.96-3.89(\mathrm{~m}, 1 \mathrm{H}), 3.86-3.78(\mathrm{~m}, 1 \mathrm{H}), 3.61-3.53$ (m, 1H), $3.51-3.45(\mathrm{~m}, 1 \mathrm{H}), 2.10(\mathrm{p}, J=6.2 \mathrm{~Hz}, 2 \mathrm{H}), 1.84-1.65(\mathrm{~m}, 2 \mathrm{H}), 1.60-1.44(\mathrm{~m}$, 4H). ${ }^{13} \mathrm{C}$ NMR $\left(101 \mathrm{MHz}, \mathrm{CDCl}_{3}\right) \delta 190.91,164.23,132.08,129.95,114.89,99.12,65.48$, 63.81, 62.51, 30.78, 29.60, 25.51, 19.72. HRMS (ESI ${ }^{+}$) calcd. for $[\mathrm{M}+\mathrm{Na}]+:$ 287.1254. Found: 287.1252 .

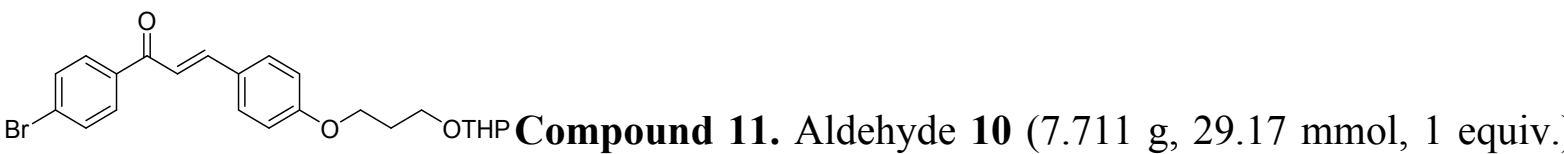
and 4-bromoacetophenone (5.807 g, $29.17 \mathrm{mmol}, 1$ equiv.) were dissolved in ethanol (100 mL). Sodium hydroxide $2.5 \mathrm{M}(100 \mathrm{~mL})$ was added dropwise at $0{ }^{\circ} \mathrm{C}$ and the solution was stirred at 
RT overnight. The reaction mixture was extracted with EtOAc, and combined organic layers washed with water and brine. The crude yellow oil was purified by column chromatography (dry loading) with PE/EtOAc 9:1 to 6:4 as eluent to yield to the desired compound (7.512 g, 58\%). ${ }^{1} \mathrm{H}$ NMR (400 MHz, $\left.\mathrm{CDCl}_{3}\right) \delta 7.88(\mathrm{~d}, J=8.6 \mathrm{~Hz}, 2 \mathrm{H}), 7.79(\mathrm{~d}, J=15.6 \mathrm{~Hz}, 1 \mathrm{H}), 7.64$ $(\mathrm{d}, J=8.6 \mathrm{~Hz}, 2 \mathrm{H}), 7.59(\mathrm{~d}, J=8.8 \mathrm{~Hz}, 2 \mathrm{H}), 7.35(\mathrm{~d}, J=15.6 \mathrm{~Hz}, 1 \mathrm{H}), 6.94(\mathrm{~d}, J=8.8 \mathrm{~Hz}, 2 \mathrm{H})$, $4.60(\mathrm{t}, J=3.4 \mathrm{~Hz}, 1 \mathrm{H}), 4.14(\mathrm{t}, J=6.3 \mathrm{~Hz}, 2 \mathrm{H}), 3.98-3.90(\mathrm{~m}, 1 \mathrm{H}), 3.88-3.81(\mathrm{~m}, 1 \mathrm{H}), 3.63$ $-3.55(\mathrm{~m}, 1 \mathrm{H}), 3.54-3.47$ (m, 1H), 2.10 (p, $J=6.2 \mathrm{~Hz}, 2 \mathrm{H}), 1.87-1.77$ (m, 1H), $1.77-1.68$ (m, 1H), $1.63-1.49(\mathrm{~m}, 4 \mathrm{H}) .{ }^{13} \mathrm{C}$ NMR $\left(101 \mathrm{MHz}, \mathrm{CDCl}_{3}\right) \delta 189.55,161.53,145.50,137.42$, $132.00,130.49$, 130.10, 127.73, 127.44, 119.18, 115.15, 99.16, 65.32, 63.97, 62.54, 30.84, 29.73, 25.58, 19.77. HRMS (ESI $\left.{ }^{+}\right)$calcd. for $[\mathrm{M}+\mathrm{H}]^{+}:$445.1009. Found: 445.1016.

(120 $\mathrm{mL})$. Diethylamine (6.168 g, $84.34 \mathrm{mmol}, 8.7 \mathrm{~mL}, 5$ equiv.) and nitromethane (5.148 g, 84.34 mmol, $4.5 \mathrm{~mL}, 5$ equiv.) were then added. The solution was refluxed overnight. After cooling down to RT, the reaction was quenched with an aquous solution of hydrochloric acid (2.5 M) until $\mathrm{pH}=2-3$. The solution was extracted with ethyl acetate and the recombined organic layers were washed with brine and dried over sodium sulfate. The solvent was evaporated and the crude orange oil (8.469 g) was used without further purification. ${ }^{1} \mathrm{H}$ NMR $\left(400 \mathrm{MHz}, \mathrm{CDCl}_{3}\right)$ $\delta 7.77(\mathrm{~d}, J=8.6 \mathrm{~Hz}, 2 \mathrm{H}), 7.60(\mathrm{~d}, J=8.6 \mathrm{~Hz}, 2 \mathrm{H}), 7.16(\mathrm{~d}, J=8.7 \mathrm{~Hz}, 2 \mathrm{H}), 6.85(\mathrm{~d}, J=8.7$ $\mathrm{Hz}, 2 \mathrm{H}), 4.77(\mathrm{dd}, J=12.3,6.9 \mathrm{~Hz}, 1 \mathrm{H}), 4.64(\mathrm{dd}, J=12.3,7.7 \mathrm{~Hz}, 1 \mathrm{H}), 4.61-4.56(\mathrm{~m}, 1 \mathrm{H})$, $4.19-4.11(\mathrm{~m}, 1 \mathrm{H}), 4.09-4.01(\mathrm{~m}, 2 \mathrm{H}), 3.94-3.77$ (m, 2H), $3.59-3.47$ (m, 2H), 3.38 (dd, $J$ $=7.0,2.2 \mathrm{~Hz}, 2 \mathrm{H}), 2.05(\mathrm{p}, J=6.3 \mathrm{~Hz}, 2 \mathrm{H}), 1.86-1.65(\mathrm{~m}, 2 \mathrm{H}), 1.61-1.46(\mathrm{~m}, 4 \mathrm{H}) .{ }^{13} \mathrm{C} \mathrm{NMR}$ $\left(101 \mathrm{MHz}, \mathrm{CDCl}_{3}\right) \delta 196.15,158.78,135.29,132.22,130.74,129.67,128.94,128.58,115.21$, 99.12, 79.92, 65.10, 64.08, 62.51, 41.75, 38.77, 30.83, 29.79, 25.58, 19.76. HRMS (ESI ${ }^{+}$) calcd. for $[\mathrm{M}+\mathrm{Na}]+:$ 528.0992. Found: 528.0987 


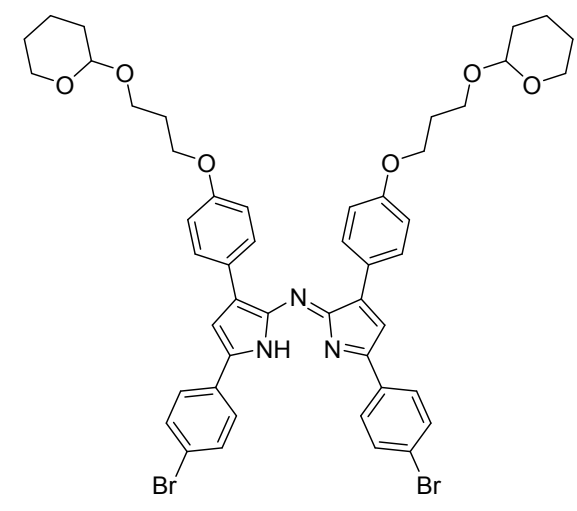

Compound 13. Crude compound 12 (8.469 g) was dissolved in butanol (90 mL). Ammonium acetate (approx. $46 \mathrm{~g}$, approx. $591 \mathrm{mmol}$, approx. 35 equiv.) was then added to the reaction mixture. The resulting solution was heated under reflux during 24h. The reaction was then cooled down to RT. The solvent was concentrated to half and the crude filtered. The isolated solid was washed thoroughly with cold ethanol to give the desired product as a purple foils (1.933 g, $2.093 \mathrm{mmol}, 25 \%$ over two steps). ${ }^{1} \mathrm{H}$ NMR (300 MHz, $\left.\mathrm{CDCl}_{3}\right) \delta 8.01-7.92(\mathrm{~m}, 4 \mathrm{H}), 7.73(\mathrm{~d}, J=8.5 \mathrm{~Hz}, 4 \mathrm{H}), 7.62(\mathrm{~d}, J=8.5 \mathrm{~Hz}, 4 \mathrm{H}), 7.03(\mathrm{~s}, 2 \mathrm{H})$, $6.95(\mathrm{~d}, J=8.8 \mathrm{~Hz}, 4 \mathrm{H}), 4.66-4.61(\mathrm{~m}, 2 \mathrm{H}), 4.24-4.13(\mathrm{~m}, 4 \mathrm{H}), 4.02-3.93(\mathrm{~m}, 2 \mathrm{H}), 3.93-$ $3.83(\mathrm{~m}, 2 \mathrm{H}), 3.68-3.58(\mathrm{~m}, 2 \mathrm{H}), 3.58-3.48(\mathrm{~m}, 2 \mathrm{H}), 2.18-2.08(\mathrm{~m}, 4 \mathrm{H}), 1.82-1.66(\mathrm{~m}$, 4H), $1.66-1.43(\mathrm{~m}, 8 \mathrm{H}) .{ }^{13} \mathrm{C}$ NMR $\left(101 \mathrm{MHz}, \mathrm{CDCl}_{3}\right) \delta 159.51,154.07,149.83,142.84$, $132.46,131.32$, 130.47, 127.91, 126.46, 124.35, 114.56, 113.56, 99.14, 65.19, 64.16, 62.52, 30.87, 29.88, 25.62, 19.78. HRMS $\left(\mathrm{ESI}^{+}\right)$calcd. for $[\mathrm{M}+\mathrm{H}]^{+}:$922.2061. Found: 922.2064.
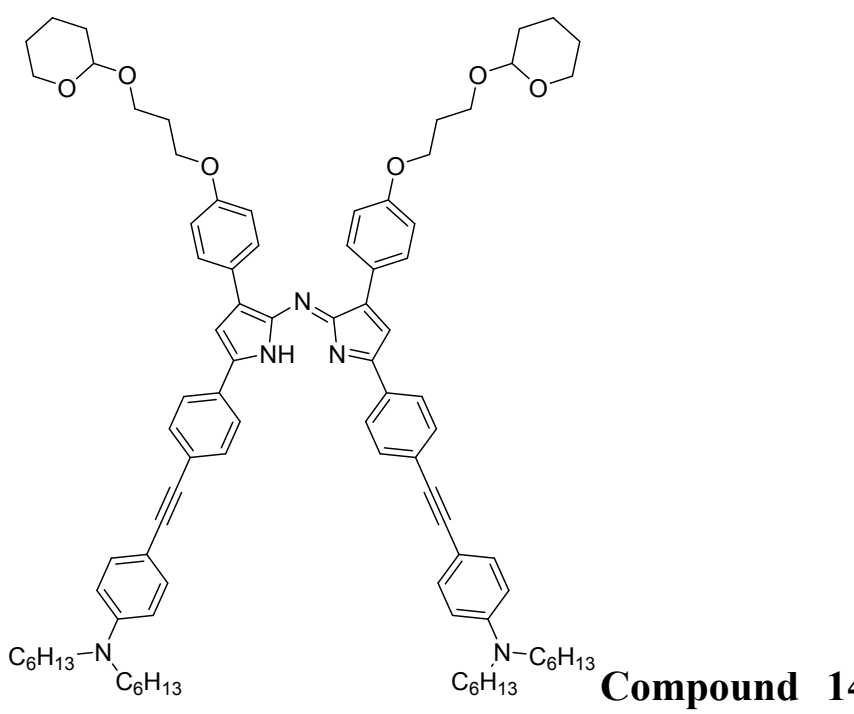

14. In a microwave reaction vessel was dissolved dipyrromethene 13 (767 mg, $0.831 \mathrm{mmol}, 1$ equiv.), 4-ethynyl-N,N-dihexylaniline (498 mg, $1.744 \mathrm{mmol}, 2.1$ equiv.) and potassium carbonate (459 mg, $3.324 \mathrm{mmol}, 4$ equiv.) in DMF $(20 \mathrm{~mL})$. The reaction mixture was degassed by bubbling argon for $30 \mathrm{~min}$. $\mathrm{Pd}\left(\mathrm{PPh}_{3}\right)_{4}$ (92 mg, $0.083 \mathrm{mmol}, 0.1$ equiv.) was then added and the mixture was heated at $100{ }^{\circ} \mathrm{C}$ with microwave irradiation for $1 \mathrm{~h}$. The reaction was washed with $\mathrm{NH}_{4} \mathrm{Cl}$, water, brine, dried over 
sodium sulfate. The solvent was evaporated under reduced pressure. The crude was directly used for the next step without further purification. ${ }^{1} \mathrm{H}$ NMR $\left(300 \mathrm{MHz}, \mathrm{CDCl}_{3}\right) \delta 8.03(\mathrm{~d}, \mathrm{~J}=$ $8.2 \mathrm{~Hz}, 4 \mathrm{H}), 7.89$ (d, J = 8.4 Hz, 4H), 7.63 (d, J = 8.2 Hz, 4H), 7.41 (d, J = 8.8 Hz, 4H), 7.12 (s, 2H), $6.98(\mathrm{~d}, \mathrm{~J}=8.7 \mathrm{~Hz}, 4 \mathrm{H}), 6.59(\mathrm{~d}, \mathrm{~J}=8.8 \mathrm{~Hz}, 4 \mathrm{H}), 4.67-4.60(\mathrm{~m}, 2 \mathrm{H}), 4.17(\mathrm{t}, J=6.3 \mathrm{~Hz}$, $4 \mathrm{H}), 4.02-3.82(\mathrm{~m}, 4 \mathrm{H}), 3.68-3.46(\mathrm{~m}, 4 \mathrm{H}), 3.34-3.24(\mathrm{~m}, 8 \mathrm{H}), 2.19-2.08(\mathrm{~m}, 4 \mathrm{H}), 1.86$ $-1.67(\mathrm{~m}, 4 \mathrm{H}), 1.66-1.46(\mathrm{~m}, 16 \mathrm{H}), 1.39-1.19(\mathrm{~m}, 24 \mathrm{H}), 0.96-0.83(\mathrm{~m}, 12 \mathrm{H})$.

(14. Dipyrromethene 14 (theoretical mass $1.108 \mathrm{~g}, 0.831 \mathrm{mmol})$ was dissolved in DCM (40 mL). Diisopropylethylamine (1.074 g, 8.31 mmol, $1.4 \mathrm{~mL}, 10$ equiv.) was added dropwise and the solution was stirred for 20 minutes under argon. $\mathrm{BF}_{3} . \mathrm{OEt}_{2}(1.769 \mathrm{~g}, 12.465 \mathrm{mmol}, 1.5 \mathrm{~mL}, 15$ equiv.) was then added. The solution was stirred at RT under argon overnight. The crude was washed with a saturated aqueous ammonium chloride solution, wwater and brine. The organic layer was collected, and the solvent evaporated. The product was purified by column chromatographyy using DCM/MeOH 95:5 as eluent to yield to a blue-green solid (545 mg, 51\% over two steps). ${ }^{1} \mathrm{H}$ NMR (400 MHz, $\left.\mathrm{CDCl}_{3}\right) \delta 8.08-7.99(\mathrm{~m}, 8 \mathrm{H}), 7.57(\mathrm{~d}, J=8.4 \mathrm{~Hz}, 4 \mathrm{H}), 7.39(\mathrm{~d}, J=8.7 \mathrm{~Hz}, 4 \mathrm{H}), 7.01-6.96$ $(\mathrm{m}, 6 \mathrm{H}), 6.58(\mathrm{~d}, J=8.7 \mathrm{~Hz}, 4 \mathrm{H}), 4.21(\mathrm{t}, J=5.9 \mathrm{~Hz}, 4 \mathrm{H}), 3.90(\mathrm{t}, J=5.6 \mathrm{~Hz}, 4 \mathrm{H}), 3.28(\mathrm{t}, J=$ $7.3 \mathrm{~Hz}, 8 \mathrm{H}), 2.15-2.05$ (m, 4H), 1.90 (s, 2H), $1.67-1.53$ (m, 8H), $1.42-1.26$ (m, 24H), 0.99 - $0.82(\mathrm{~m}, 12 \mathrm{H}) .{ }^{13} \mathrm{C}$ NMR $\left(101 \mathrm{MHz}, \mathrm{CDCl}_{3}\right) \delta 160.25,157.88,148.33,145.90,143.25$, $133.31,131.38,131.02,130.33,129.65,127.15,125.60,117.70,114.81,111.35,108.55,94.83$, 87.98, 65.88, 60.35, 51.13, 32.10, 31.85, 27.34, 26.95, 22.83, 14.19. HRMS (ESI ${ }^{+}$) calcd. for $[\mathrm{M}+\mathrm{H}]^{+}:$1212.7283. Found: 1212.7311 . 


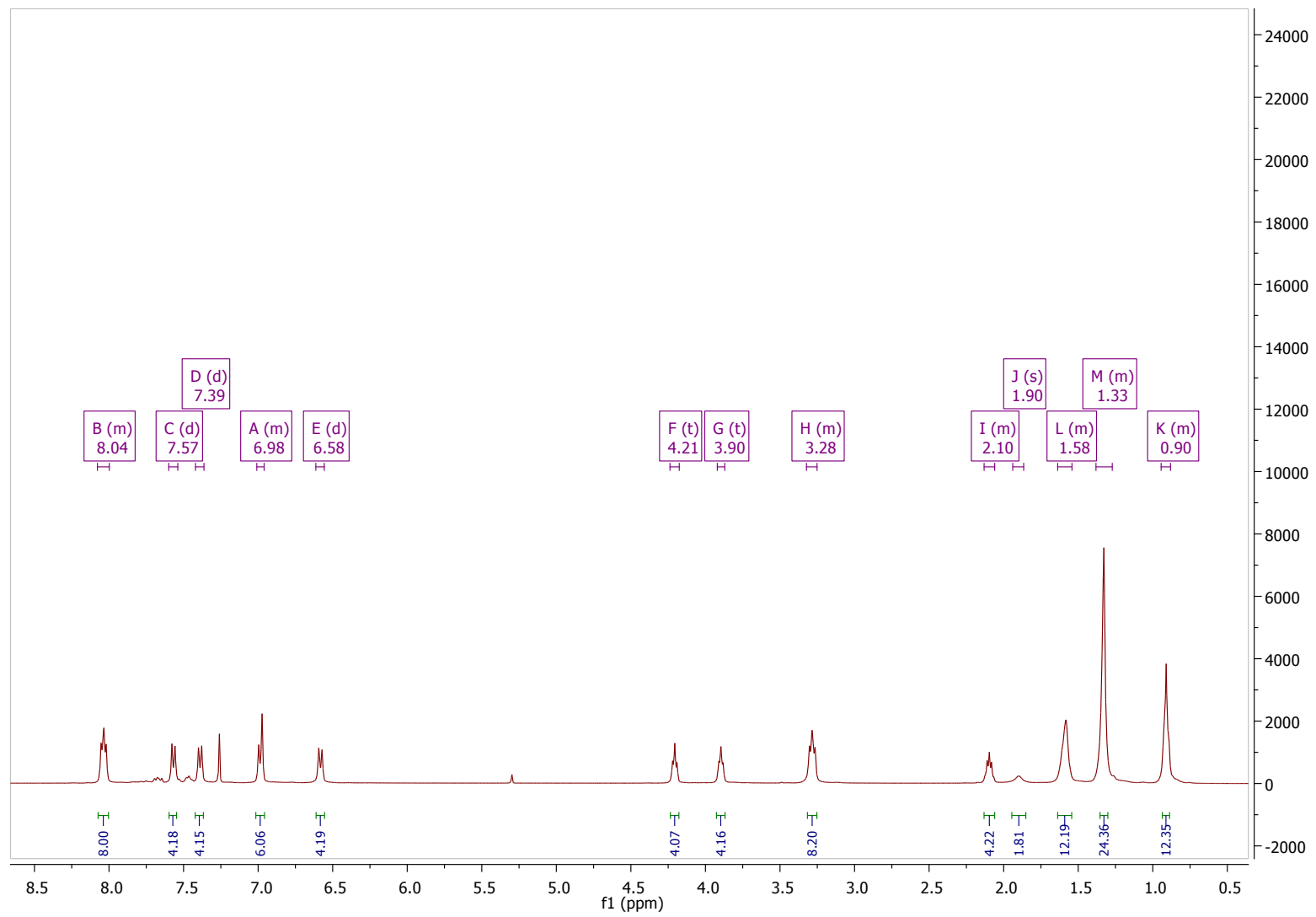

Figure S12. ${ }^{1} \mathrm{H}$ NMR spectrum $\left(\mathrm{CDCl}_{3}\right)$ of compound 15

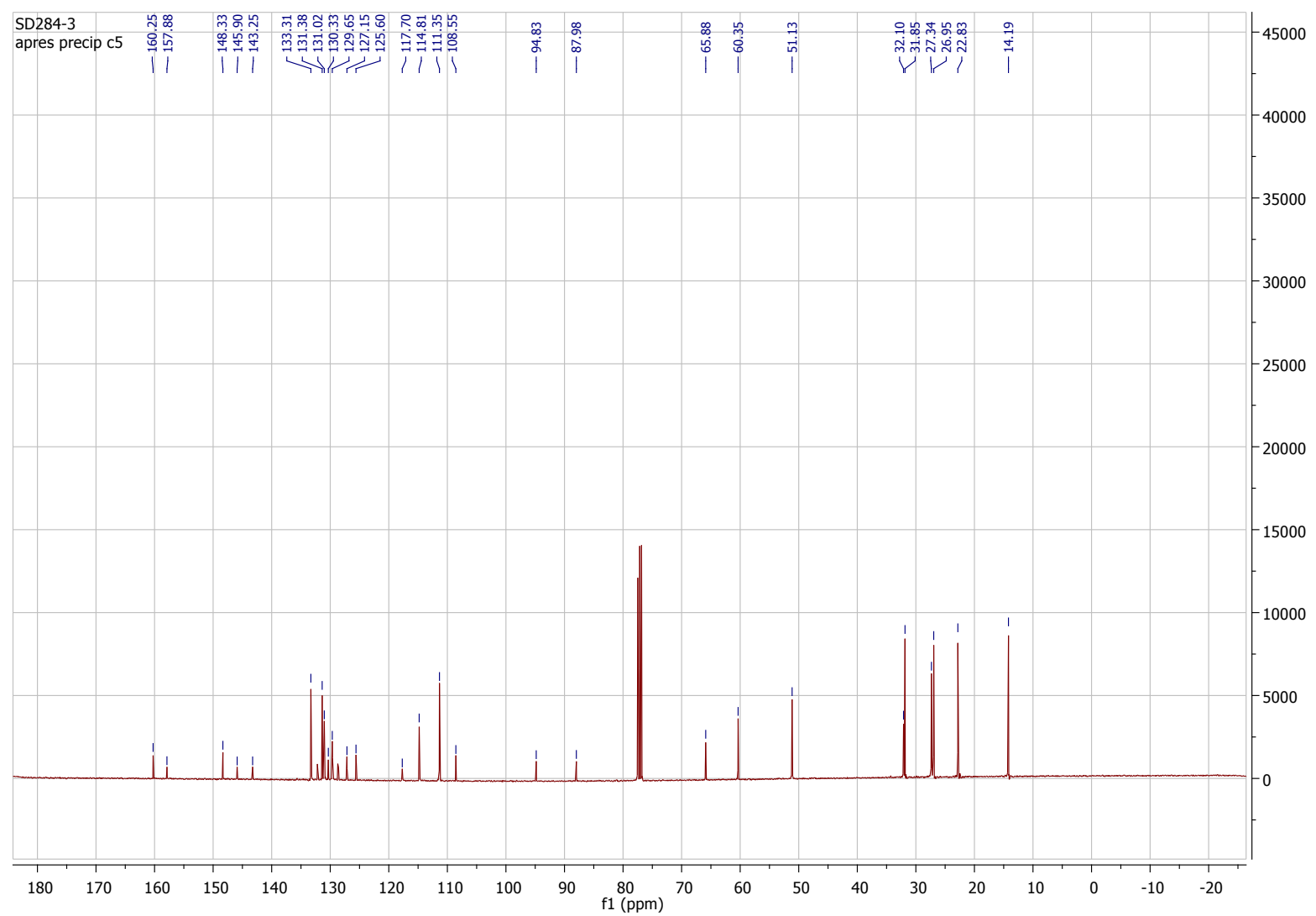


Figure S13. ${ }^{13} \mathrm{C}$ NMR spectrum $\left(\mathrm{CDCl}_{3}\right)$ of compound 15

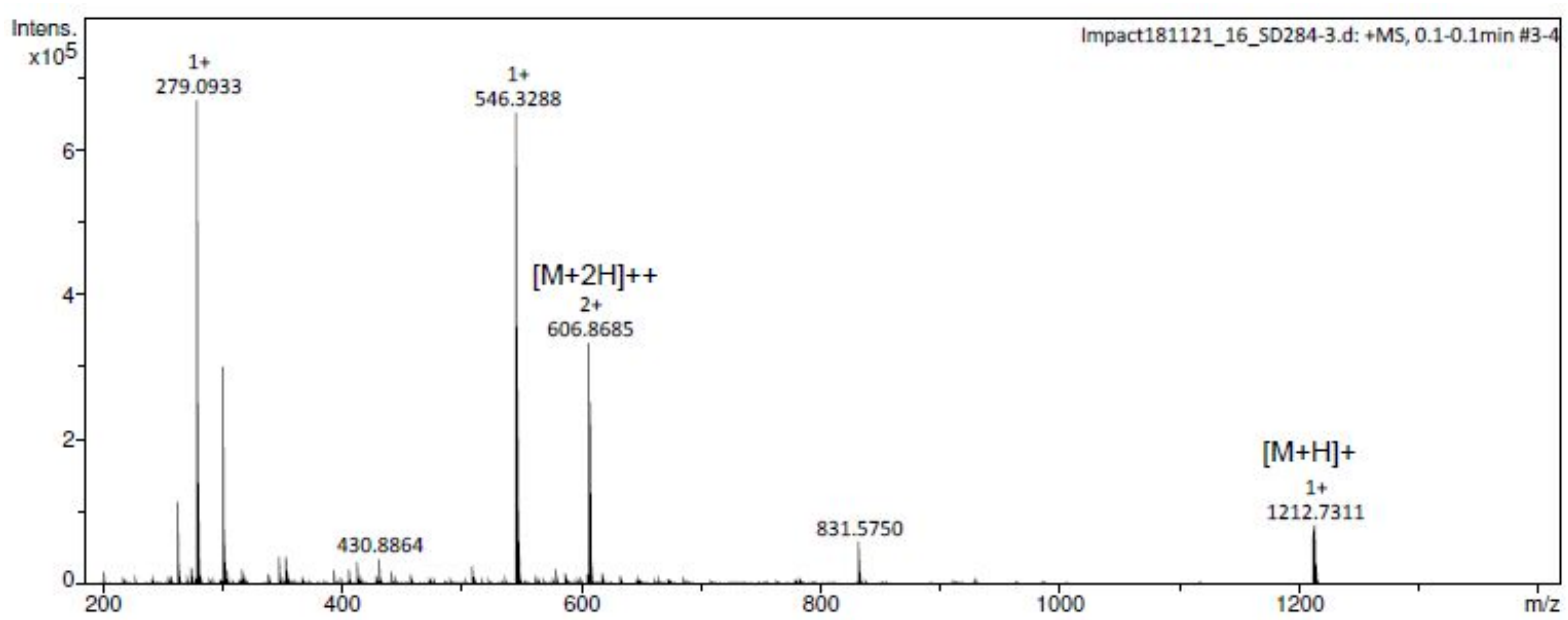

Figure S14. HRMS spectrum of compound 15

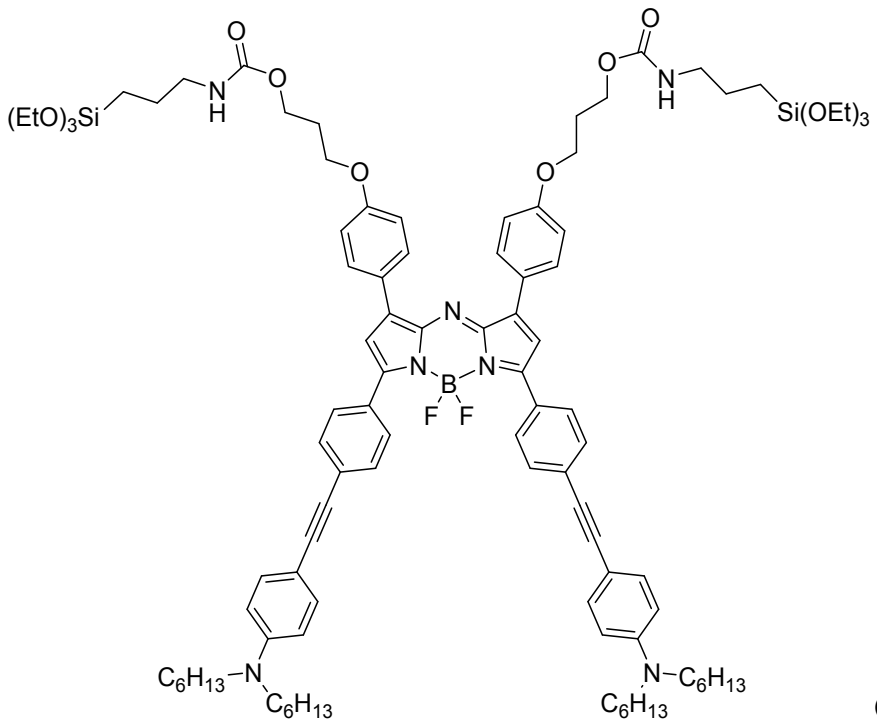

Compound 2. Aza-bodipy 15 (100 mg, $0.078 \mathrm{mmol}, 1$ equiv.) was dissolved in dry THF. ICPTES (46 mg, $0.187 \mathrm{mmol}, 2.4$ equiv) and DBTDL (2.5 mg, approx. $5 \mathrm{~mol} \%$ ) were then added and the resulting mixture was stirred under argon overnight. After the solvent was removed under vacuum, the mixture was recrystallized in $\mathrm{MeOH}$ to yield to the desired product as a blue solid (129 mg, 95\%). ${ }^{1} \mathrm{H}$ NMR (300 MHz, $\left.\mathrm{CDCl}_{3}\right) \delta 8.05(\mathrm{~d}, J=8.3 \mathrm{~Hz}, 8 \mathrm{H}), 7.57(\mathrm{~d}, J=8.5 \mathrm{~Hz}, 4 \mathrm{H}), 7.39(\mathrm{~d}, J=8.8 \mathrm{~Hz}, 4 \mathrm{H}), 7.03-$ $6.93(\mathrm{~m}, 6 \mathrm{H}), 6.58(\mathrm{~d}, J=8.9 \mathrm{~Hz}, 4 \mathrm{H}), 4.98(\mathrm{br} \mathrm{s}, 2 \mathrm{H}), 4.29$ (t, $J=5.8 \mathrm{~Hz}, 4 \mathrm{H}), 4.15$ (t, $J=6.0$ $\mathrm{Hz}, 4 \mathrm{H}), 3.81$ (q, $J=7.0 \mathrm{~Hz}, 12 \mathrm{H}), 3.28$ (t, $J=7.3 \mathrm{~Hz}, 8 \mathrm{H}), 3.22-3.13(\mathrm{~m}, 4 \mathrm{H}), 2.20-2.12$ (m, 4H), $1.69-1.49(\mathrm{~m}, 12 \mathrm{H}), 1.41-1.30(\mathrm{~s}, 24 \mathrm{H}), 1.22$ (t, $J=7.0 \mathrm{~Hz}, 18 \mathrm{H}), 0.99-0.88$ (m, $12 \mathrm{H}), 0.63(\mathrm{~d}, J=8.2 \mathrm{~Hz}, 4 \mathrm{H}) .{ }^{13} \mathrm{C} \mathrm{NMR}\left(101 \mathrm{MHz}, \mathrm{CDCl}_{3}\right) \delta 160.33,157.95,156.67,148.34$, $145.91,143.36,133.31,131.39$, 130.99, 130.36, 129.66, 127.17, 125.60, 117.77, 114.87, $111.35,108.56,94.79,87.96,64.80,61.53,58.61,51.14,43.57,31.86,29.22$, 27.35, 26.96, 
23.44, 22.83, 18.43, 14.19, 7.81. HRMS $\left(\mathrm{ESI}^{+}\right)$calcd. for $[\mathrm{M}+\mathrm{H}]^{+}$: 1706.9763. Found: 1706.9811 .

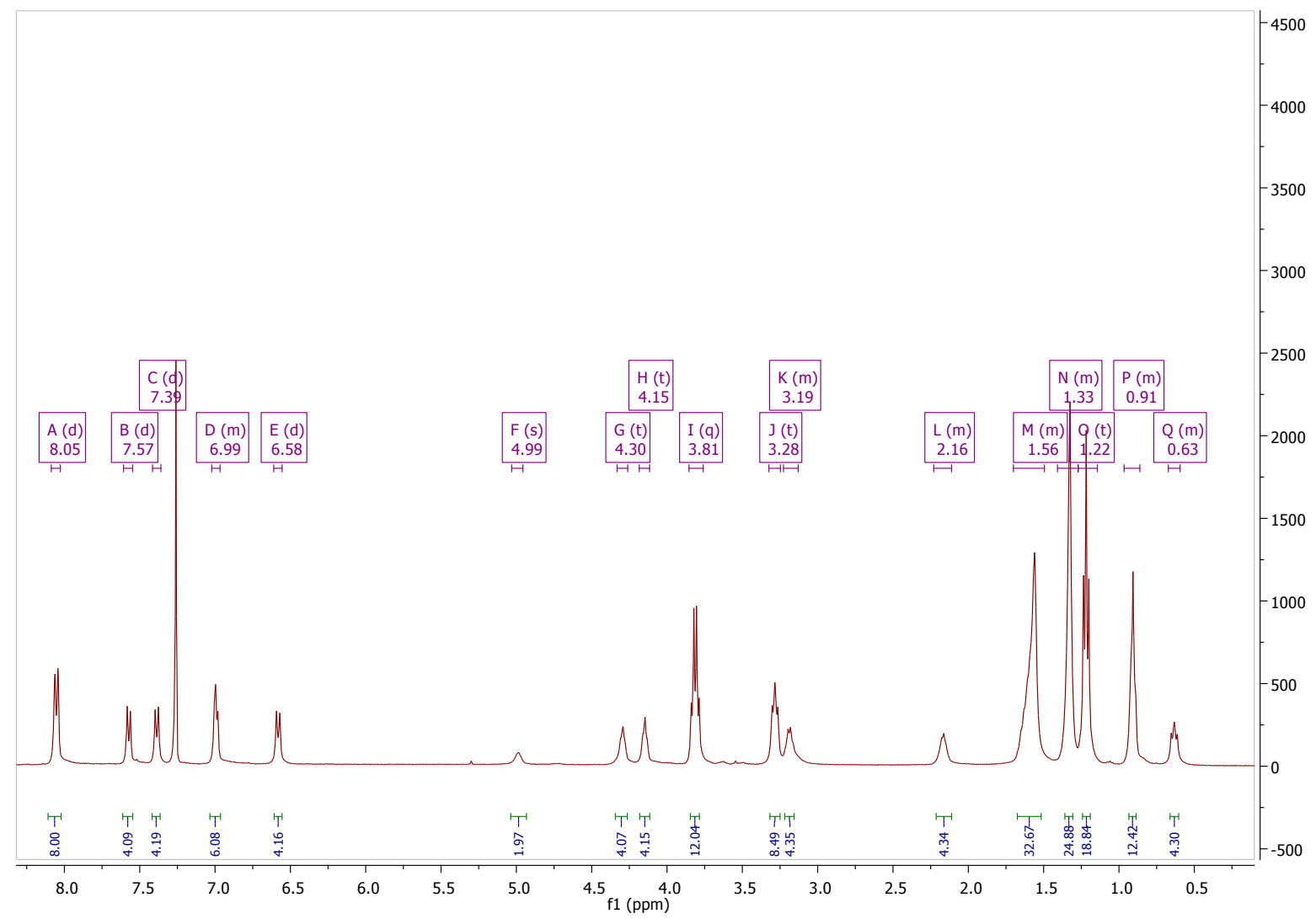

Figure S15. ${ }^{1} \mathrm{H}$ NMR spectrum of compound 2 


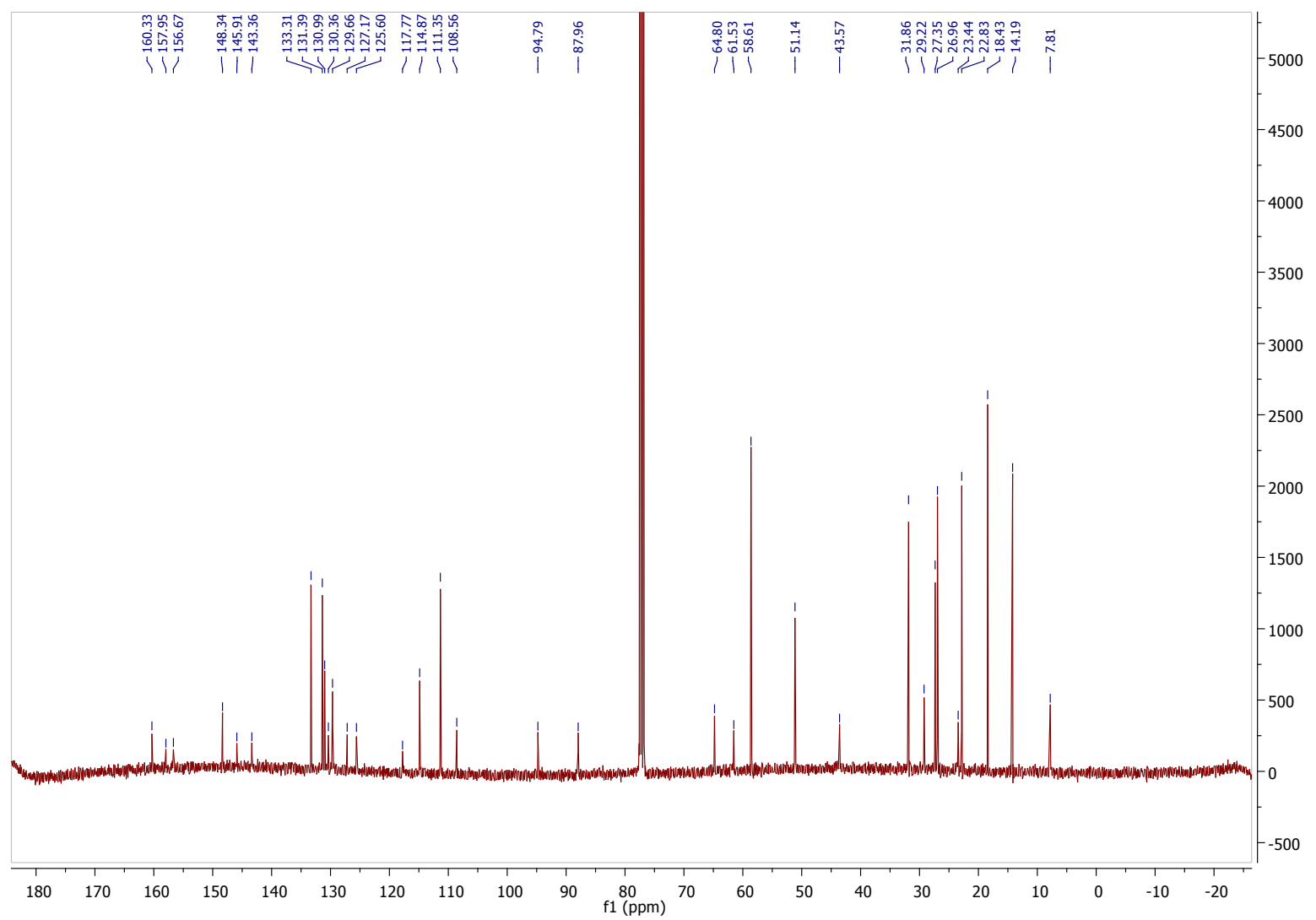

Figure S16. ${ }^{13} \mathrm{C}$ NMR spectrum of compound 2

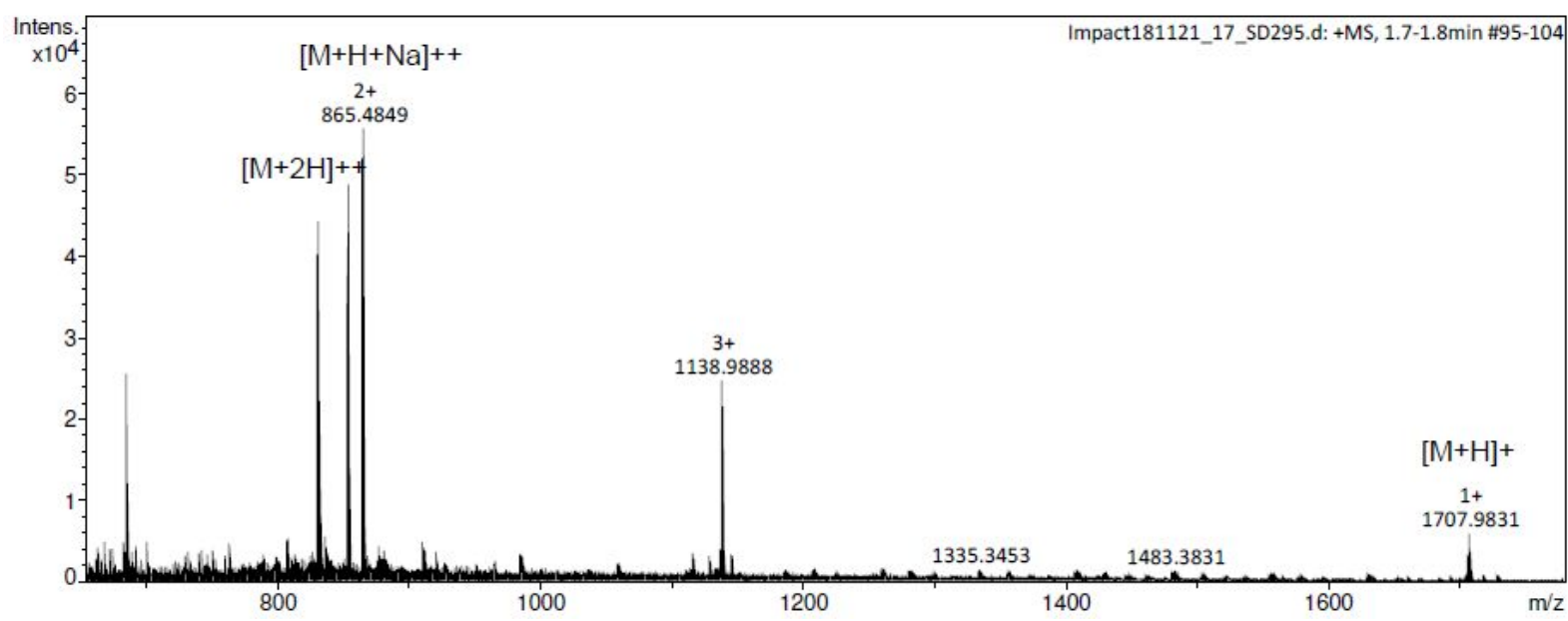

$\begin{array}{rlrrr}\text { Meas. } \mathbf{m} / \mathbf{z} & \text { lon Formula } & \mathbf{m} / \mathbf{z} & \text { err [ppm] } & \text { mSigma } \\ 853.9927 & \text { C98H136BF2N7O12Si2 } & 853.9918 & -0.2 & 22.0 \\ 864.9837 & \text { C98H135BF2N7NaO12Si2 } & 864.9828 & -0.3 & 14.8 \\ 1706.9811 & \text { C98H135BF2N7O12Si2 } & 1706.9763 & -2.0 & 162.5\end{array}$

Figure S17. HRMS spectrum of compound 2 


\section{References}

1. Corredor, C. C.; Belfield, K. D.; Bondar, M. V.; Przhonska, O. V.; Yao, S., One- and twophoton photochemical stability of linear and branched fluorene derivatives. J. Photochem. Photobiol., A 2006, 184 (1), 105-112.

2. Sheik-Bahae, M.; Said, A. A.; Wei, T.; Hagan, D. J.; Stryland, E. W. V., Sensitive measurement of optical nonlinearities using a single beam. IEEE J. Quantum Electron. 1990, 26 (4), 760-769.

3. Rulliere, C., Femtosecond Laser Pulses: Principles and Experiments. Springer-Verlag New York: 2005; p 426.

4. Frisch, M. J.; Trucks, G. W.; Schlegel, H. B.; Scuseria, G. E.; Robb, M. A.; Cheeseman, J. R.; Scalmani, G.; Barone, V.; Petersson, G. A.; Nakatsuji, H., et al. Gaussian 16 Rev. A.03, Wallingford, CT, 2016.

5. Yanai, T.; Tew, D. P.; Handy, N. C., A new hybrid exchange-correlation functional using the Coulomb-attenuating method (CAM-B3LYP). Chem. Phys. Lett. 2004, 393 (1), 51-57. 6. Chibani, S.; Le Guennic, B.; Charaf-Eddin, A.; Maury, O.; Andraud, C.; Jacquemin, D., On the Computation of Adiabatic Energies in Aza-Boron-Dipyrromethene Dyes. J. Chem. Theory Comput. 2012, 8 (9), 3303-3313.

7. Cammi, R.; Mennucci, B., Linear response theory for the polarizable continuum model. $J$. Chem. Phys 1999, 110 (20), 9877-9886.

8. Caricato, M.; Mennucci, B.; Tomasi, J.; Ingrosso, F.; Cammi, R.; Corni, S.; Scalmani, G., Formation and relaxation of excited states in solution: a new time dependent polarizable continuum model based on time dependent density functional theory. J. Chem. Phys. 2006, 124 (12), 124520.

9. Vérité, P. M.; Guido, C. A.; Jacquemin, D., First-principles investigation of the double ESIPT process in a thiophene-based dye. PCCP 2019, 21 (5), 2307-2317.

10. Le Bahers, T.; Adamo, C.; Ciofini, I., A Qualitative Index of Spatial Extent in ChargeTransfer Excitations. J. Chem. Theory Comput. 2011, 7 (8), 2498-2506.

11. Aidas, K.; Angeli, C.; Bak, K. L.; Bakken, V.; Bast, R.; Boman, L.; Christiansen, O.; Cimiraglia, R.; Coriani, S.; Dahle, P., et al., The Dalton quantum chemistry program system. WIREs Computational Molecular Science 2014, 4 (3), 269-284.

12. Lunden, H. PhD Thesis. Linköping University, 2019.

13. Bouit, P.-A.; Kamada, K.; Feneyrou, P.; Berginc, G.; Toupet, L.; Maury, O.; Andraud, C., Two-Photon Absorption-Related Properties of Functionalized BODIPY Dyes in the Infrared Range up to Telecommunication Wavelengths. Adv. Mater. 2009, 21 (10-11), 1151-1154. 14. De Filippis, B.; Linciano, P.; Ammazzalorso, A.; Di Giovanni, C.; Fantacuzzi, M.; Giampietro, L.; Laghezza, A.; Maccallini, C.; Tortorella, P.; Lavecchia, A., et al., Structural development studies of PPARs ligands based on tyrosine scaffold. Eur. J. Med. Chem. 2015, $89,817-25$. 